\title{
Fıkıh Usulü Tarihinde Dört Temel Şerî̂ Delil Tertibinin Gelişimi
}

\author{
Ahmet Temel \\ Dr. Öğretim Üyesi, İstanbul Üniversitesi İlahiyat Fakültesi, İslam Hukuku Anabilim Dalı \\ Assistant Professor, Istanbul University Faculty of Theology, Department of Islamic Law \\ İstanbul, Turkey \\ ahmet.temel@istanbul.edu.tr \\ orcid.org/ 0000-0001-8589-117X
}

\section{The Development of the Four Fundamental Sources Order in the History of Islamic Legal Theory}

\section{Abstract}

This study deals with the four-source order, which is commonly accepted in the Sunni legal theory, within the limits of a historical investigation of Islamic legal theory. This article aims to determine in which phases this recognition has occurred and with what sort of changes. The majority of extant usūl works that have been produced in different traditions and some other sources in different disciplines have been defined as the research universe of this study. Among them, those which could represent these works have been cited in this article. Since it was designed as a historical investigation and evaluation study, some dimensions of the subject that may be of interest in terms of legal philosophy and theory are not included in the analysis. These topics some of which have already been studied in certain works are suggested for further research.

In this article, two main questions are addressed: First, the question of which actors have historically contributed to the acceptance of the four-source order in the form of kitāb, sunna, ijmā' and qiyās. On this point, contrary to what is claimed in some contemporary scholarship, it has been revealed that the thesis that al-Shāfiī was the responsible authority for this four-source order is not accurate. It is seen that the scholars living in the second to fourth centuries A.H. mentioned these four sources together with different sources such as reason, definite deduction, sense, language, recurrent reports and famous narrations. Among these, al-Jașșāș’ explanation as to whether qiyās can be counted as a source together with kitāb, sunna, and ijmā', which is the main subject of discussion in the next periods, has significantly illuminated the rational ground for qiyās to take place in this four-source order. Beginning with the fifth century, the tendency to restrict the notion of dalil to definitive sources, had a consequence in the direction of excluding qiyās from the apparatus of source order; hence it was generally accepted that the sources were limited to kitāb, sunna, and ijmā' during that time. However, in the same century, it seems that jurist-theoreticians made the claims that qiyās should be recognized together with these three sources. At this point, it seems that the Hanafi theoreticians, especially al-Pazdawi and al-Sarahsī, took an important step of expanding their acceptance of the main sources by claiming qiyās as the fourth source after mentioning the three main sources as kitāb, sunna, and ijmā'. Al-Sam ‘ānī, who could be regarded as a contemporary of them and who had been

İtihal Taraması/Plagiarism Detection: Bu makale intihal taramasından geçirildi/This paper was checked for plagiarism Geliş/Received: 10 Ocak/January 2020|Kabul/Accepted: 10 Mart/March 2020|Yayın/Published: 20 Mart/March 2020 Atff/Cite as: Ahmet Temel, "Fıkıh Usulü Tarihinde Dört Temel Şer î Delil Tertibinin Gelişimi = The Development of the Four Fundamental Sources Order in the History of Islamic Legal Theory", Eskiyeni 40 (Mart/March 2020), 73-94. https://doi.org/10.37697/eskiyeni.673398

Copyright (C) Anadolu Illahiyat Akademisi/Anatolian Theological Academy, 06050, Ankara, Turkey |www.anilakademi.com CC BY-NC 4.0 | This paper is licensed under a Creative Commons Attribution-NonCommercial License 
once in the Hanafĩ school before shifting to the Shāfi'î school, gives us the most obvious testimony of this transition. He lists the three sources as aṣl and others as ma'qūl al-așl, a classification developed by some Shāfi'ī jurist-ușūl scholars including al-Baghdādī and al-Shirāzī. However, instead of this classification, he states that the order of the sources developed by jurists in the form of kitāb, sunna, ijmā', and qiyās is more accurate. The Ash'arī theologian-theoreticians of the time including al-Juwaynī, al-Ghazālī also defend an attitude against counting qiyās among main sources by limiting three sources as kitāb, sunna, and ijmā‘. Since the logic-oriented ușūl works marked the style of uṣūl traditions to a great extent afterwards, the understanding of the theologian-theoreticians who excluded qiyās from the sources and highlighted the three main sources continued to be effective in the sixth and seventh centuries A.H.. However, Fakhr al-Dīn al-Rāzī, the important ușūl scholar of the period, provides strong evidence that the four-source order have increased its effect during that time. In his famous tafsīr work, al-Rāzī states that "the jurists accepted the sources of the sharīa in the form of kitāb, sunna, ijmā', and qiyās", while he retains the three-source order in his ușūl work. Even though he does not explicitly promote four-source order in his ușūl work, he does list these four sources when mentioning the sources of the judgments in a topic. As a matter of fact, although alRāzī refrains from mentioning four-source order clearly, one of his leading followers al-Bayḍāwī does explicitly state this four-source order at the beginning of his work. Unlike his theologian-theoretician predecessors, al-Āmidī does not hesitate to include qiyās in the scope of shar'î dalīi, but he maintains the same reservation by classifying three sources as primary and qiyās and istidlāl as secondary. It is understood that the "three plus one classification" initiated by al-Pazdawi and al-Sarahsī was preserved by the Hanafĩ ușūl scholars of the sixth century A.H. such as al-Lāmishī, al-Samarqandī, alUsmandī. However, it is seen that in the seventh century A.H., beginning with Ibn al-Sā'ầtī, this order started to be pointed out directly in the form of four sources without the need of mentioning classification in the form of three plus one. When the eighth century A.H. is reached, the order of four sources have started to be pointed out with a special term as al-adillat al-arba $a^{a}$ (the four sources). In the same century, the Mālikī scholar Ibn Juzay al-Kalbī and Ḥanbalī scholar Ibn Muflih give the shar'ĩ dalīls in the form of kitāb, sunna, ijmā', and qiyās, which shows that this order was established by the eighth century A.H..

The second question is the one of when the term al-dalil al-shar'i started to be used for the sources of sharī‘a and when it was settled. The term ușūl, from which the title of this scientific discipline was derived, was widely used in the early periods to indicate the sources of shari'a. Although by time different terms such as hujja, burhān, amāra, and dalīl were used simultaneously for the sources of sharīa, the term dalī gained a greater acceptance over time. The Hanafī uṣūl scholars, probably beginning with ‘īsā b. Abān used the term ḥujja (pl. hujaj) more dominantly for a long time. The Hanafi ușūl scholars, even al-Dabūsī, who used the term of dalīl in the title of his ușūl work, preferred the term hujja until Ibn al-Sāaàtī. In addition to being one of the first scholars representing the change in the classification of sources in the Hanafi tradition, Ibn al-Sā'ātī stands out also one of the first Ḥanafī scholars in preferring the term dalìl over the term hujja. This research has shown that these two elements can be mentioned in the answer to the question of how Ibn al-Sā'ātī, who is mostly listed in the first place, by the authors who mention mamzūj styled uṣūl (arguably claimed to be a hybrid style between the theologianoriented and jurist-oriented writings) works, differed from his Hanafĩ predecessors. The main actors, however, in the domination of the term of the al-dalil al-shar'i in the literature of Islamic legal theory were the theologian-theoreticians. The leading scholar responsible for this usage was Abū al-Ḥusayn al-Bașrī, who used this term consistently for the first time throughout his work. After al-Bașrī, theologian-theoreticians, whether Mu'tazilī or Ash'arī, preferred the term dalīl for sources of sharīa. Yet, it took a few more centuries for Shāfi'ì and Ḥanafĩ ușūl scholars to widely settle this term for that meaning.

Keywords: Islamic Law, al-Dalīl al-Shar'ī, History of Islamic Legal Theory, Ușūl, Fiqh 


\section{Fıkıh Usulü Tarihinde Dört Temel Şerî̉ Delil Tertibinin Gelişimi}

Öz

Sünnî fikıh usulünde yaygın bir kabul olan kitap, sünnet, icmā‘ ve kıyas şeklindeki dörtlü şer'î delil tertibini bir fikh usulü tarihi incelemesi çerçevesinde ele alan bu çalşsma bu kabulün hangi evrelerde ve ne gibi değişikliklerle ortaya çıktığını tespit etmeyi amaçlamaktadır. Farklı te'lif gelenekleri içerisinde üretilmiş ve günümüze kadar ulaşmış fikı usulü eserlerinin büyük bir bölümünü ve fikıh usulü eseri olmasa da bu konuya değinen çeşitli alanlardaki kaynaklar makalenin araştırma evreni olarak tanımlanmış bunlardan temsil kabiliyeti olanlar da çalışmada atfa değer kabul edilerek zikredilmiştir. Tarihsel tespit ve değerlendirme çalışması olarak kurgulandığından makalede konunun hukuk felsefesi ve teorisi bakımından ilgi çekici olabilecek boyutları bir kısmı zaten yapılmış olan başka araştırmalara havale edilerek analiz kapsamına alınmamıştır.

Bu makalede iki temel soru cevaplanmaya çalş̧ılmıştır: Birincisi, kitap, sünnet, icmā‘ ve kıyas şeklinde deliller tertibinin kabul görmesinde tarihsel olarak hangi aktörler ne oranda katkı sağlamıştır sorusudur. Bu noktada kimi çağdaş araştırmalarda iddia edilenin aksine Şăfiłî̉nin bu delil tertibinde belirleyici otoriteye sahip olduğu yönündeki tezin isabetli olmadığı ortaya konmuştur. Hicrî ikinci ilâ dördüncü asırlarda yaşayan usulcülerin bu dört delili akıl, açık istinbat, duyu, dil, haber, meşhur rivayetler gibi farklı delillerle bir arada zikrettikleri görülmektedir. Bunlar arasında Ceșșaș̣’ın sonraki dönemlerin temel tartışma konusu olan kıyasın kitap, sünnet ve icmā‘ gibi bir delil sayılıp sayılamayacağına ilişkin yaptı̆̆ı izah, kıyasın bu dörtlü delil tertibinde yerini almasındaki rasyonel zemini önemli ölçüde aydınlatmıştır. Zira hicrîbeşinci asırla birlikte başlayan delil kavramını kat'î delile hasretme eğilimi kıyası deliller tertibinin dışına çıarma yönünde bir sonucu doğurmuş; delillerin kitap, sünnet ve icmā‘ şeklinde sınırlanması genel kabul görür hale gelmiştir. Ancak aynı asrında sonlarında fakih-usulcülerin kıyasın bu üç delile dâhil edilmesi gerektiği noktasındaki iddiaları makes bulmuş görünmektedir. Bu noktada özellikle Pezdevī ve Serahsī başta olmak üzere Hanefî usulcülerin üç delili kitap, sünnet ve icmā‘ şeklinde zikredip hemen ardından kıyasın da dördüncü delil olduğunu iddia etmeleriyle bu üç delil kabulünü genişletmenin önemli adımını attıklarını göstermektedir. Onların bir akranı sayılabilecek olan ve önceleri Hanefî iken Şâfi'î mezhebine intisap eden Sem‘ānī bize bu geçişin en belirgin tanıklığını yapmaktadır. Sem‘ānī kendi döneminde şöhret bulan ve Baǵdādī ve Şirāzī gibi bazı Şâfiî̀ fakih-usulcülerin geliştirdiği anlaşılan üç delili aṣl şeklinde sıralayarak bunun dışındakileri ise ma'kūulu'l-aṣl şeklinde ayıran tasnife işaret eder. Ancak bu tasnif yerine fakihlerin kitap, sünnet, icmā‘ ve kıyas şeklindeki sıralamalarının daha isabetli olduğunu ifade eder. Cuveynī, Ġazālī gibi Eş’arî kelamcı-usulcüler de kitap, sünnet ve icmā‘ şeklinde üç delili deliller başlığında zikrederek kıyasın bunlar arasında sayılmasına karşıt bir tutumu savunurlar. Ġazālī sonrasında mantık yönelimli fikıh usulü eserlerinin fikıh usulü te'lif geleneklerini önemli ölçüde şekillendirmesi nedeniyle kelamcı-usulcülerin kıyası deliller dışında tutan ve üç temel delili öne çıkaran anlayışı hicrî altıncı ve yedinci asırlarda etkisini sürdürmeye devam etmiş görünmektedir. Ancak dönemin önemli usul âlimi Fahreddīn er-Rāzi dört delil tertibinin etkisini iyiden iyiye arttırdığı noktasında güçlü bir delil sunmaktadır. Rāzī, kendi usul eserinde kelamcı-usulcülerin üç delil tertibini muhafaza ederken tefsir eserinde fakih usulcülerin şeriatın asıllarını kitap, sünnet, icmā‘ ve kıyas şeklinde dörtlü tertibi kabul ettiklerini söyler. Aynı zamanda açıkça bu tertibi esas alarak te'lif etmemiş olsa da usul eserinde hükümlerin kaynaklarını zikrederken bu dört delili sıralar. Nitekim Rāzī açıkça zikretmekten kaçınsa da onun etkilediği isimlerin başlarında gelen takipçilerinden Beyḍāvī eserinin başında bu dörtlü tertibi kabul eder. Āmidīnnin ise selefi olan kelamcı-usulcülerin aksine kıyası şer î delil kapsamına almaktan çekinmediği ancak aslî ve ferî̀ ayrımı üzerinden kıyası yine de fer'î deliller kapsamında değerlendirerek aynı çekinceyi sürdüğü görülür. Hicrî altıncı asırda Hanefî usulcüler cephesinde Pezdevĩ ve Serahsıīnnin başlattı̆̆g üç artı bir şeklindeki tasnifin Lāmişī, Semerḳandī, Usmendī gibi usulcüler tarafından korunduğu anlaşılmaktadır. Ancak hicrî yedinci asırda İbnu's-Sāaātī ile birlikte üç artı bir şeklindeki tasnife de ihtiyaç duymaksızın dört delil şeklinde doğrudan bu tertibe işaret edilmeye başlandığı görülmektedir. Hicrî sekizinci asra gelindiğinde ise bu dört delile artık el-edilletu'l-erba $a$ şeklinde 
özel bir ıstılahla işaret edilmeye başlandığını Hanefi usulcülerden Șadru'ş-şerīa ve Eş̧arî kelamcıusulcülerden de Ebū's-Senenā el-İșfahānīnnin eserlerinde görmeye başlamaktayız. Aynı asırda Mâlikî usulcü İbn Cuzey el-Kelbī ve Hanbelîusulcü İbn Mufliḥ'in de artıkşerî delilleri kitap, sünnet, icmā‘ ve kıyas şeklinde dörtlü tertip ile vermesi bu tertibin tam olarak hicri sekizinci asırda sünnî fikıh usulünde yerleştiğini gösterir.

İkinci soru ise şerî̀ deliller için şerî delil teriminin ne zaman kullanılmaya başladığı ve yerleştiği sorusudur. Bu ilme adını veren ușūl (asıllar) sstılahı ilk dönemlerde yaygın olarak kullanılırken zamanla buna ek olarak ḥuccet, burhān, emāre, delil gibi farklı terimlerin eş zamanlı olarak kullanıldı̆̆ı görülse de bunlar arasından şerî delil ıstılahının zamanla daha büyük bir kabule mazhar olduğu anlaşılmaktadır. Hanefî usulcülerin muhtemelen 'Īsā b. Ebān ile başlayarak bunlar arasından daha çok huuccet (ç. hucec) terimini uzun bir süre daha baskın bir biçimde kullandığı görülmektedir. Eserinin başlığında delil kavramını kullanan Debūsī de dâhil olmak üzere Hanefi usulcüler İbnu's-Să'ātì'ye kadar bu terimi tercih etmişlerdir. Tipkı deliller tasnifinde Hanefî usul geleneğindeki değişikliktekarşımıza çıkan ilk isimlerden olduğu gibi delil ıstılahını ḥuccet ıstılahına tercih etmek bakımından da İbnu's-Sāaātī öne çıkmaktadır. Memzuc usul eserlerini sıralayan müelliflerin çoğunlukla ilk sıralarda zikrettiği İbnu's-Sā‘ātì'nin bu tür bir eser te'lif etmekle nasıl bir farklllık ortaya koyduğu sorusuna cevap sadedinde bu iki unsurun da zikredilebileceğini bu araştırma göstermiştir. Şer î delil teriminin fikıh usulünde baskın hale gelmesinde asıl önemli aktörler kelamcı-usulcüler olmuştur. Bunların başında da bu terimi eseri boyunca istikrarlı bir biçimde ilk kez kullanan Ebü'l-Huseyn el-Bașrī gelmektedir. Bașrī sonrasında Mu'tezilî olsun Eş'arî olsun kelamcı usulcüler delil ıstılahını tercih etmişler şâfi'î̀ve Hanefî fakih-usulcüler için ise bu ıstılahın yerleşmesi için birkaç asır geçmesi gerekmiştir.

\section{Anahtar Kelimeler}

İslam Hukuku, Şer‘ Delil, Fıkıh Usulü Tarihi, Usul, Fıkıh

\section{Giriş}

Delil kavramı farklı bazı anlamlara işaret eden çeşitli tanımlamalara sahip olan ve İslami ilimler arasında sıklıkla başvurulan ortak mefhumlardan biridir. Kelam, felsefe, mantık, fikıh ve fikıh usulü ilimlerinde kullanılan bu kavramın ortak genel bir tarifi "bir önermenin doğruluk ve meşruiyetini gösteren unsur veya dayanak” şeklinde yapılabilir. Fıkıhta "iddiaların ispat araçları" ve bir hükmün kaynaklardaki cüz’î dayanağı manasında kullanılan delil, fikıh usulünde de bu ikinci manaya yakın olarak fikıhta bir hükme ulaşmak için kullanılan kaynak ve metotların bir tertip içerisinde icmâlî olarak değerlendirildiği şerî̂ deliller bahsinde karşımıza çıar. Ușūlu'l-fiḳh ${ }^{1}$ terkibindeki ușūl ve tekili aṣl bu şerî̂ delilleri ifade eden kavramlardan biridir. Dolayısıyla fikıh usulü ilminin esasında "fıkhın delilleri" anlamına geldiği ve bu deliller hakkında sistematik bilgi üretmeyi amaçlayan bir ilim olduğu söylenebilir. Nitekim fikıh usulü literatüründe herhangi bir kitabın içeriği dikkate alınırsa fikı usulü konularının doğrudan ya da dolaylı olarak şerî delillerle ilgili olduğu görülür. Fıkıh usulü ilmi de tarihsel olarak bu deliller üzerindeki teorik tartışmalarla başlamış ve bu tartışmalar üzerinde bağımsız bir ilim dalı haline gelmiştir.

Şerî̂ delil, İslâmî ilimlerde herhangi bir iddianın yapılabilmesi için gerekli dayanağı teşkil ettiğinden tüm ilim dallarının ilgi alanına girer. Bu nedenle fikıh usulü meselelerinin çok büyük bir çoğunluğunun doğrudan delil bahsiyle ilgili olması şaşırtıcı değildir. Fıkıh

1 Bu çalışmada şahıs isimleri ve eser başlıkları ile bir terimin orijinal yazımının vurgulandığı yerlerde transliterasyon yapılmış; bunun dışında Türkçede yaygın akademik kullanımı yerleşmişözel mezhep ve grup isimleri ile terimlerde ise yaygın yazım biçimi esas alınmıştır. 
usulü ilminin de teşekkülünden itibaren ana başlıklarını oluşturan deliller bahsinde sünnî fikıh usulü tarihinin bir noktasından itibaren kitap, sünnet, icmā‘ ve kıyas biçiminde sıralanan dört şer'î delil tertibi şekillenmiş görünmektedir. Tarihin belli bir noktasında diyorum, zira her ne kadar bu şekilde yapılan bu tertip sanki hep böyleymişçesine bir algı oluşturacak güçlü bir otoriteye sahip hale gelmişse de klasik dönem kaynaklarının önemli bir bölümü tam olarak bu sıralamayı vermemektedir. Bu makale, bir fikıh usulü tarihi araştırması olarak dört şerî delil şeklindeki tertibin hangi süreçler sonucunda ne zaman ortaya çıktığını ve nasıl büyük bir kabule mazhar olduğunu incelemektedir. Bu temel inceleme konusu zorunlu olarak birtakım ilişkili soruları da beraberinde getirmektedir: Neden başka deliller olmasına rağmen dört şer‘̂i delil ile sınırlandırılmaya gidilmiştir? Gerek fikıh gerekse fikıh usulü literatürlerinde çok sık başvurulmasına rağmen birtakım deliller neden aslî şerî̀ deliller arasında zikredilmemiş hatta örf gibi bazıları fikı h usulü kitaplarında kendilerine hiç yer bulamamıştır? Buna karşılık modern dönemde yazılmış fikıh usulü eserleri neden klasik dönemdeki bu tavrı korumamış ve pek çok delili aslî ve fer'î deliller şeklinde ayırarak kitabın kapsamına dâhil etmişlerdir? Bu sorulara, makalenin temel konusu olan dört şerî̀ delil tertibinin tarihsel gelişim süreci ve deliller arasındaki hiyerarşik mertebeler çerçevesinde cevap aranacaktır. Bu konuya girmeden önce delil kavramı, bu kavramın eş değer kavramlarıyla bir arada ele alınacak ve ardından dört şerî delil şeklindeki tertibin tarihi süreci incelenecektir.

Konuyu incelemeye geçmeden önce konu hakkında çağdaş literatürü değerlendirmek isabetli olacaktır. Ne var ki neredeyse tüm fikıh usulü çalışmalarının ilişkili sayılabileceği bu konu hakkında literatür değerlendirmesi yapmak ilk bakışta zor görünebilir. Bu noktada makalenin konu sınırlamasını tekrar vurgulamak elzemdir. Bu makale bahsi geçen delillerin mahiyetleri bakımdan bir tarihsel incelemeyi değil; dört şer î delil tertibinin kavramsal olarak teşekkül serencamını incelemeyi amaçlar. Bu nedenle bu delillerin mahiyetlerine ilişkin sorular ne kadar ilgi çekici olsa da bu araştırmanın kapsamı dışındadır. Bu tahdid ile değerlendirme konusu olacak çalışmalar oldukça daralmış olacaktır. Şer'î delillerin mahiyetine ilişkin belirli zaman dilimlerini ele alan çok sayıda çalışma varken; şer î delillerin tertibinin tarihsel gelişimini ele alan çalışma pek azdır. Her ne kadar şer'î delillerin tarihsel gelişimini değil; bunlar arasındaki hiyerarşiyi dikkate alan bir çalışma da olsa Saliha Kasapoğlu'nun Şerî̉ Delillerde Öncelik Meselesinin Mezhep-Delil Perspektifinden Tahlili ve Anlama Yöntemine Etkileri başlıklı çalışması zikredilebilir. ${ }^{2}$ Bu çalışmanın temel amacı şer̂̂̂ delilleri, yazarın mezhep ve delil eksenli şeklinde niteliği yaklaşımlar çerçevesinde sübut ve delalet bakımından tercih önceliğine göre değerlendirmektir. Ehl-i re’y ve ehl-i hadis yaklaşımları zemininde ele aldığı bu konu bizim çalışmamızda deliller arası hiyerarşik tertip şeklinde değineceğimiz tâlî konumuza yakındır. Birtakım değerli tespitler yapan Kasapoğlu, konuyu tarihsel gelişim sürecini esas alarak değil; delil merkezli ve mahiyet ekseninde bir hukuk felsefesi çalışması şeklinde incelemiştir. Bu çalışma ise fikıh usulü tarihi araştırması yapan bir tespit ve değerlendirme çalışması olacaktır. Başlı̆̆ındaki benzerlik itibarıyla burada zikredilebilecek bir diğer çalışma da 2005 yılında Malezya'da yapılan

Saliha Kasapoğlu, “Şer’î Delillerde Öncelik Meselesinin Mezhep-Delil Perspektifinden Tahlili ve Anlama Yöntemine Etkileri,” Hitit Üniversitesi İlahiyat Fakültesi Dergisi 17/34 (2018), 763-776. 
Tertibu'l-edilleti'ş-şer'iyye el-muttafak 'aleyhā 'inde'l-cumhūr ve tenziluhu min hilāli kaḍāyā'tta'ārudi ve't-tercịh isimli yüksek lisans tezidir. ${ }^{3}$ Bu tezde de araştırmacı ittifak edilmiş dört delilin birbirlerine nazaran mertebesini ve bunun fikhî ihtilaflara etkisini ele almış; bu tertibin tarihsel gelişimini incelememiştir.

\section{Delil Kavramı}

\subsection{Delilin Lugat ve Ist1lah Anlamları}

Delālet ve dulūlet masdarından türeyen delil sözlükte yol gösteren, rehber, kılavuz anlamlarına gelmektedir. Çoğulu edille ve delāil şeklinde kullanılır. ${ }^{4}$ Şerî delil fikıh usulü literatüründe "üzerinde doğru düşünmek suretiyle haberî bir sonuca (matlub-1 haberî) ulaştıran şey" olarak tanımlanır. ${ }^{5}$ Tanımda yer alan matlub-ı haberî şer'î amelî hükme, doğru düşünme (en-naẓaru's-ṣahịh) ise usulüne uygun ictihad faaliyetine işaret eder. İstenen sonuca ulaştıran şeyin mahiyeti hem kendisinden bilgi edinilen kaynağı, hem de bu bilgi üretmeden kullanılan yöntemi ifade ettiğinden, şerî delilin rafine bir tarifi "müctehidin şer'î amelī bir hükme ulaşmak için ictihad faaliyetinde başvurduğu kaynak ya da yöntem" şeklinde yapılabilir. Kimi kaynaklarda delil kavramının sadece kat'ī delile hasredilerek zannī delilin emare şeklinde adlandırıldığı görülse de çoğunluk bu zannī-kat ‘̄i ayrımını delil kavramı içinde yapmayı tercih etmiştir. Bu konuya tarihsel süreci içinde aşağıda daha detaylı olarak dönülecektir.

Delil sözcüğü Kur'an'da sadece bir yerde zikredilir ve burada güneşin gölgelerin uzayıp kısalmasını sağlayan asıl sebep olduğu sadedinde güneş, delil sözcüğü ile ifade edilir. ${ }^{6}$

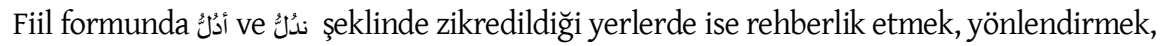
göstermek, işaret etmek anlamlarında kullanılır. ${ }^{7}$ Hadis metinlerinde de delil sözcüğüne yalnızca sözlük anlamı olan kılavuz, rehber anlamlarında rastlanır. ${ }^{8}$ Delil sözcüğü yerine şer'î hükmün dayanağını ifade etmek üzere așıl, burhān, beyyine, hüccet gibi kelimeler kullanılır ki bu da delil sözcügünün bu kelimelerin yerini almasının ve kavramsallaşmasının geç bir döneme tekabül ettiğini gösterir. Bu konuya da aşağıda daha detaylı bir inceleme içinde döneceğiz.

Delil kavramı kelam, mantık ve felsefede de öne çıkan kavramlardandır. Ġazālī (505/111) delili mantık ilmi içinde "bilgi ortaya çıkaran iki zorunluöncülün birleşimi” şeklinde tanımlarken; Cürcānī (816/1413) "bilinmesiyle bir başka şeyin bilgisine ulaşılan şey"

3 Muștafā Muhammed Cebrī Şemsu'd-dīn, Tertibu'l-edilleti'ş-şer'iyye el-muttafak 'aleyhā 'inde'l-cumhūr ve tenzīluhu min hilāli kadāāyāt-ta'ārudi ve't-tercịh, (Malezya: Uluslararası İslam Üniversitesi, Yüksek Lisans Tezi, 2005).

4 Ebū'l-Faḍl Cemālüddīn Muhammed b. Mukerrem İbn Manẓūr, Lisānu'l-'Arab, 3. Basım (Beyrut: Daru Sâdr, 1414), 11/248.

5 Ebû'l-Hasen Seyfuddīn ‘Alī b. Muhammed b. Sālim es-Sa'lebī el-Āmidī, el-i̇hkām fì ușūli’l-ahkām, thk. 'Abdurrezzāk Afífí (Beyrut: el-Mektebu'l-İslāmī, n.d.), 1/9.

6 Furkan, 25/45: "Rabbinin gölgeyi nasıl da uzattı̆̆ını görmez misin? Dileseydi elbette onu sabit kılabilirdi. Ancak biz güneşi gölgenin kendisine bağlı olduğu bir sebep (delil) kıldık"

7 A'raf 7/22; Taha 20/55, 120; Kasas 28/12; Sebe 34/7, 14; Saf 61/10.

8 Örneğin bk. Ebū 'Abdullah Muhammed b. İsmâ‘īl b. İbrāhīm el-Buhārī, el-Cāmitu'l-musnedu'ș-șahịhu'lmuhtașar min umūri Rasūlillah sallallāhu 'aleyhi ve sellem ve sunenihi ve eyyāmihi, thk. Muhammed Zuheyr b. Nāṣır (b.y.: Dāru tavk en-necāt, n.d.) Kitābu'l-icāre, 3. 
şeklinde daha genel bir biçimde tanımlar. ${ }^{9}$ Kelamda delil ile duyu organlarıyla algılanamayan ve zaruri olarak bilinemeyen şeylerin bilgisine ulaştıran şeyin kastedildiği görülür. Bununla birlikte delil farklı türler şeklinde incelenerek farklı tanımlar yapılmış ve şer̂̂ delile bu tasnif içerisinde yer verilmiştir. Bu tasniflerden biri delilin kaynağı bakımından aklî delil, naklî delil ve vaḍiì delil şeklindedir. Aklî delil ile medlulüne zatı ile doğrudan delalet eden delil kastedilir. Bu delil dini bir metne dayalı olmadığı gibi bir öncüle dayalı (vaḍ̂ī) da değildir. Aklî delile bir örnek olarak Allah'ın varlığı için kelamda kullanılan hụūūs delili zikredilebilir. Vaḍ̂i delil ile ise bir öncüle dayalı önerme kastedilir ki örneği dilde belli manaları ifade eden lafızlardır. Naklî delil ifadesi ile de fikıh usulünde zikredilen şerî deliller kastedilir.

\section{2 Şerî̂ Delili İfade İçin Kullanılan Kavramlar}

Şerî delil yerine kullanılan ilk kavramlardan biri asıldır. Sözlükte bir şeyin alçak bölümü, üzerine başka bir şeyin bina edildiği temel ve kök anlamlarına gelen asıl, ${ }^{10}$ ușūlu'lfikh terkibinde de çoğuluyla bu ilmin ismi olarak kullanılmıştır. Hükümlerin kaynakları zikredilirken çoğunlukla aṣl ve aṣlın çoğulu olan uṣulün erken dönemlerde sıklıkla kullanıldığı görülür. Ușūl kelimesi benzer bir şekilde uṣūlu'd-dīn, uṣūlu't-tevhīid, uṣūlu'ssunne, ${ }^{11}$ uṣūlu'l-futyā terkiplerinde kullanılmış ve kullanıldığı bağlamdaki ilim dalının öne çıkan ve diğer başlıkların kendisinden türediği konular kastedilmiştir. Şerî deliller zikredilirken bunlar arasında temel deliller yahut ittifak edilen deliller anlamında da el-ușūl ifadesinin kullanıldığına bazı geç dönem eserlerinde de rastlanır. ${ }^{12}$

Delil manasında kullanılan kavramlardan biri hüccettir. Sözlükte kasıt, burhan, hasma karşı kendisiyle savunulan ya da husumet esnasında kendisiyle zafere ulaşlan şey şeklinde tanımlanan hüccet, ${ }^{13}$ erken dönem fikıh ve fikıh usulü literatüründe sıklıkla hem icmālī hem de tafșìlī delil anlamında kullanılmıştır. Burada icmālī delil ifadesiyle fikıh usulünde zikredilen kitab, sünnet, icmā‘, klyas gibi teorik genel delilleri, tafṣilī delil ifadesiyle de herhangi bir fer'ī meselede kullanılan özel bir delili, örneğin abdestin farzlarına ilişkin Maide suresinin 6. ayetinin delil olmasını kastediyoruz. Bu manada hüccet erken dönem literatüründe bazı fikıh usulü eserlerine isim olmasının yanı sıra diyalektik tartışmalarda da muarızdan delil isterken yahut delil serdederken sıkça başvurulan bir kavram olmuştur.

Delil manasında kullanılan bir diğer kavram olan burhan, Arapçada b-r-h kökünden olup açığa kavuşturmak, berraklaştırmak anlamına gelir. Burhan ile delil arasındaki fark

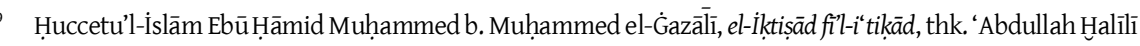
(Beyrut: Dār al-kutub al-'ilmiyyah, 2004), 19; 'Alī b. Muhammed el-Curcānī, et-Ta'rîfāt (Beyrut: Dāru'lkutubi'l-'ilmiyye, 1983), 104.

10 İbn Manz̄ūr, Lisānu'l-'Arab, 11/16.

11 Geniş bir değerlendirme için bk. Ahmet Temel, "Ușūl al-sunna: The Tenets of Islamic Orthodoxy and Orthopraxy According to the Traditionalists (Ahl al-hadith)," in The Sunna and its Status in Islamic Law, thk. Adis Duderija, 9781137376. Basım (New York: Palgrave Macmillan, 2015), 39-57.

12 Örneğin bk. Ebū Muhammed Muvaffakuddīn ‘Abdullah b. Ahmed b. Muhammed İbn Kudāme, Ravdatu’nnāẓır ve cunnetu'l-munāzir fi ușūli'l-fikh 'alā mezhebi'l-İmām Ahmed b. Hanbel, thk. 'Abdulkerīm b. 'Alī b. Muhammed En-Nemle, 2. Basım (Riyad: Mu'essesetu'r-reyyān, 2002), 1/192.

13 İbn Manzūr, Lisānu'l-'Arab, 2/228.
} 
üzerine bazı dilciler burhanın zorunlu bilgi ifade ettiğini delilin ise zan ifade ettiğini öne sürer. ${ }^{14}$ Özellikle kelamî tartışmalarda ve cedel örneklerinde sıklıkla kullanılan burhan kavramına erken dönem fikıh usulü eserlerinde de rastlanır. Nitekim meşhur usul âlimi Cuveynī eserine el-Burhān fï ușūli'l-fikh ismini vermiştir.

Delil yerine kullanılan kavramlardan olan beyyine ise sözlükte açıklık, fasıla, delil, burhan ifadeleriyle tanımlanır. ${ }^{15}$ Bir iddianın dayanağı anlamında yine cedel örneklerinde sıklıkla rastlanan beyyine kavramı fikıh usulü tartışmalarında da kitab ya da sünnetten serdedilen delil manasında kullanılır. ${ }^{16}$ Daha yerleşik kullanımı ise muhakeme usulünde ispat vasıtası manasında "beyyine iddia edene, yemin ise inkâr edene düşer" şeklindeki hadisin kaideleşmesi şeklinde karşımıza çıkar. ${ }^{17}$

Sözlük anlamı itibariyle alamet, işaret anlamlarına gelen emare ${ }^{18}$ ise kat ̂̂ delil ile zannî delili ayırt etmede başvurulan bir kavramdır. Buna göre medlulüne katiyetle işaret eden şey delil iken; zan yahut tereddüt ile işaret eden şeye ise emare denerek bir ayrıma gidildiği görülür. ${ }^{19}$ Bununla beraber benzer bir ayrım aslî deliller ile fer'î deliller arasında yapılarak fer'î delillere emare dendiği de görülür.

Delil kavramı yerine kullanılan asıl, hüccet, burhan, beyyine ve emare kavramlarını tanıdıktan sonra şimdi delil kavramının fikıh usulünde kaynak ve metotları kapsayacak bir biçimde yerleşmesini tarihsel olarak incelemeye geçebiliriz.

\section{Dört Şerî Delil Tertibinin Tarihsel Gelişim Süreci}

\section{1 Şi’a ve İbādiyye'de Anahatlarıyla Delil Tertibi}

Sünnī fıkıh usulü literatüründe yerleşmiş olan dört așlī delil tertibinin mahiyeti ve tarihine geçmeden önce, şia usulünde așlī şerî̀ deliller konusuna değinelim. İmamīyye fikıh usulünde kıyas delili reddedilir. İcmā' ise ilk dönem Şi'īimamī âlimleri tarafından reddedilse de daha sonra icmā‘ın masum imamı kapsaması gerekçesiyle kabul edileceği şeklinde bir te'life gidildiği anlaşılmaktadır. Bu nedenle geç dönem Şi'î-imamī fikıh usulünde temel şerî̀ deliller kitab, sünnet, icmā‘ ve akıl şeklinde formüle edilir..$^{20}$

Zeydiyye'de ise fikı usulü gerek kaynakları ve meseleleri gerekse de bu meselelere yaklaşımı bakımından imāmīyyeden çok sünni fikıh usulüne yakınlık gösterir. İlk dönem

14 Ebū Hilāl 'Askerī, el-Furūḳu'l-luġaviyye, thk. Muhammed İbrahim Selim (Kahire: Dāru'l-'ilm ve'śekāfe, n.d.), 97.

15 İbn Manẓūr, Lisānu'l-'Arab, 13/67.

16 Erken dönemlerdeki kullanımına örnekler için bk. Ebu Abdullah Muhammed b. Hasan b. Ferkad elHanefi Şeybani, el-Hücce alâ ehli'l-Medine, thk. Mehdi Ḥasen el-Keylânî El-Ḳ̂â̂r̂̂ (Beyrut: 'Alemü'l-kütüb, 1982), 2/164, 563.

17 Ebû Zeyd 'Abdillâh b. Muhammed b. 'Ömer b. İsâ Debûsî, Takvîmu'l-edille, thk. Halîl Muhyiddin el-Meys (b.y.: Dâru'l-kutubi'l-'ilmiyye, 2001); Ebū Bekr Aḥmed b. 'Alī er-Rāzī Ceșsāạ, el-Fușūl fi'l-uṣūl, thk. Uceyl Cāsim en-Neșemī, 2. Basım (Kuveyt: Vizāratu'l-evkāfi'l-Kuveytiyye, 1994).

18 İbn Manzūr, Lisānu'l-'Arab, 1/153.

19 Ebū'l-Vefā 'Alī b. 'Akịl b. Muhammed İbn ‘Akịl, el-Vāḍih fi uṣūli'l-fikh, thk. 'Abdullâh b. 'Abdulmuhsin etTurkî (Beyrut: Mu'essesetu'r-risâle, 1999), 1/38; Ceșșāṣ, el-Fușūl fi'l-ușūl, 4/259.

20 Seyyid el-Murtaḍā es-, ezz-Žerî a, thk. Ebū'l-Kāsim el-Kercī (Tahran: Danişgah, 1927), 1/143; Ebū Ca'fer eşŞeyh et-Tūsī, el-‘Udde fi ușūli'l-fikh, thk. Muhammed Mehdi Necej (Muessesetu Āli Beyt, n.d.), 1/37-39. 
Zeydī imamlardan Ḳāsim er-Ressī (246/860) ve el-Hādī ile'l-haḳk (298/911) kelami perspektiften deliller arasında kitap, sünnet ve icmā‘ın ardından kıyas yerine aklı zikretse de en-Nātık bi'l-haḳk (424/1033) ile başlayan klasik dönem âlimleri deliller arasında akıl yerine yahut onunla birlikte kıyası zikreder. Çağdaş bir Zeydī ilim adamı da kitabında Zeydiyye'nin dayandığı delilleri aṣlī ve șānevī olarak ikiye ayırarak aṣlī delillerin kitab, sünnet, icmā’ ve kıyas olduğunu; șānevī deliller arasında ise istiḥsān, istiṣhāa, el-meșāliḥu'l-mursele, 'örf gibi delillerin olduğunu söyler. Ayrıca aklın da en büyük delil olduğunu ve dört așlī delil sonrasında onları kuşatan bir delil olarak ele alınması gerektiğini söyler. ${ }^{21}$

İbāḍi fikıh usulü alanında ilk isim olarak karşımıza Ceșșāș’ı çağdaşı olan İbn Bereke (4/10. asır) çıkmaktadır. Ebū Ḥanife ve ashabının taklidi terviç ettiğini iddia eden İbn Bereke, delilin bulunduğu durumda taklidin caiz olmayacağını söylerken delilleri de "kitab, sünnet, icmā' veya 'aḳıl hücceti” olarak sıralar. ${ }^{22}$ Daha sonraki dönemler için iḅadiyyenin en etkili âlimlerinden olan Vercelānīnnin (570/1175) de eserinde delilleri sıraladığı iki farklı yerde iki farklı tertibi zikrettiği görülür. Bunlardan birinde delilleri “Allah'ın kitabı, peygamberin sünneti, ümmetin icmāsı, salihlerin eserleri, aklî delil, his, kıyas ve sezgi” şeklinde zikreder. Diğerinde ise Vercelānī kitab, sünnet, icmā‘ ve $\mathrm{k}_{1} 1^{23}$ şeklinde bir tertibe yer verir. ${ }^{24}$ Öte yandan Vercelānī gerek ed-Delïl ve'l-burhān'da gerekse el-'Adl ve'l-inșāf adlı eserlerinde şer'ī delilleri așl, ma'ḳūlu'l-aṣl ve istișhāābu ḥāli'l-aṣl şeklinde üçlü bir tasnif içerisinde sıralar. Buna göre așl içerisinde kitab, sünnet ve icmā'; małḳūlu'l-aṣl içerisinde ise laḥnu'l-ḩitāb, fehvāll-ḩitāb ve ma'nāl-hiitāb; istiṣhābu ḥāli'l-aṣl içerisinde ise berā'etu'żzimme, şag̉lu'ż-żimme ve istiḥsānı zikreder. ${ }^{25} \mathrm{Bu}$, hicrî 5 . asırda ilk olarak Şâfî̂̀ usulcüler tarafından kullanılan așl ve ma‘ḳullu'l-aṣl şeklindeki genel taksimin İbâdî bir usulcüde etkisini göstermesi açısından dikkat çekicidir.

İmāmī, Zeydī ve İbāḍi fikıh usulünde şerî̀ delillere genel olarak değindikten sonra sünnī fikıh usulünde yerleşen kitap, sünnet, icmā', kıyas şeklindeki dört temel delil tertibinin tarihine geçebiliriz.

\subsection{Sünnī Fikıh Ușūlünde Deliller Tertibinin Tarihi}

\section{Hicrî 2. - 4. Asırlar: Deliller Tertibinde İhtilaf ve Teessüsün İlk Adımları}

Sünni fikıh usulü literatüründe kitab, sünnet, icmā, kıyas şeklinde dört temel şer̂̂̂ delil tertibinin ilk kim tarafından kullanıldığını tam olarak tespit etmek güçtür. Ebū Hilāl el-'Askerī, (395/1005) Cāhịiz’den hakikatin konuşan kitab, ittifak edilen haber, akıl ve icmā şeklinde dört kaynak (vecih) yoluyla bilineceğini zikreden ilk kişinin Vāṣil b. Ațā’ (131/748)

21 Murtad̄ā b. Zeyd el-Mahațerī, ez-Zeydiyye, thk. Yahya el-Ceyūrī (San'a: Mektebetu Bedr, 2014), 55.

22 'Abdullah b. Muhammed İbn Bereke, Kitābu'l-cāmi' (Umman: Vizāretu’t-Turās ve'ś-Śekāfe, 2007), 1/543.

23 Çağdaş bir araştırmada akıl yerine kıyas ifadesine yer verilmişse de eserde kıyas lafzı geçmemektedir. Bk. Feyza Doğruyol - Süleyman Akkuş, “Bir İbâzî Âlim Ebû Ya'kûb el-Vercelânî’nin ed-Delîl ve'l-Burhân'1 Bağlamında İbâziyye'nin Temel Görüşleri,” Sakarya Üniversitesi İlahiyat Fakültesi Dergisi (SAUIFD) 21/39 (2019),125-126 (el-Vercelānī, ed-Delīl ve'l-burhān, 1/35; 2/37'den naklen).

24 Ebū Ya'kūu el-Vercelānī, ed-Delìl ve'l-burhān, thk. Sālim el-Hārisisī, 2. Basım (Umman: Vizāretu't-Turās ve'śSekāfe, 2006), 2/37.

25 Vercelānī, ed-Delīl ve'l-burhān, 1/14; Ebū Ya'kūu el-Vercelānī, el-'Adl ve'l-inșāf (Umman: Vizāretu't-Turās ve's-Sekāfe, 1983), 3/8. 
olduğu yönündeki iddiasını aktarır. ${ }^{26}$ Ceșșāṣ, Muḥammed b. el-Ḥasen eş-Şeybānīnnin “fikıh dört yol ile elde edilir: Kitab, resulullahtan gelen sünnet ve benzeri; sahabenin üzerinde icmā‘ ve ihtilaf ettiği ve benzeri; Müslümanların güzel gördüğgu ile benzeri” şeklindeki ifadesini aktarır. ${ }^{27}$ Bu atıf eğer doğruysa ${ }^{28}$ Şeybānīnin zihninde kitab, sünnet, sahabe icmā'1 ve her asırda gerçekleşen icmā‘ olmak üzere dörtlü bir tertibin olduğu; kıyası ise bunların benzerlerini de hükme dâhil etme yöntemi olarak telakki ettiği anlaşılmaktadır.

Günümüze ulaşan fikıh usulü eserleri arasında kronolojik olarak bu tertibe yer veren ilk eser aynı zamanda bize ulaşan ilk usul eseri olarak da bilinen Şāfi'înin er-Risāle'sidir. Pek çok araştırmacı Şāfi'ī’nin er-Risāle adlı eserini bu dört temel delil üzerinden okumuş ve onun bu eserde asıl maksadının bu dört delili temel şerî deliller olarak tahkim etmek olduğunu öne sürmüştür. Şāfiłî, bu dört delili "kimsenin bir şey hakkında bir bilgi kaynağı olmaksızın helal ya da haram demesi caiz olmaz. Bilginin kaynakları da kitab, sünnet, icmā‘ ve kıyastan elde edilen haberdir" şeklinde zikreder..$^{29}$ Ancak bu dörtlü tertibi eserinin delil teorisini oluşturan iskeleti olarak görmek pek mümkün görünmemektedir. Zira beyan teorisinin kaynaklarını sıralarken icmā‘ı zikretmez. Bazen kaynakları iki ya da üç olarak zikrettiği de görülür. ${ }^{30}$ Bütün bunları dikkate alınca ilk usul eserinde dört temel şerî̀ delilin geç dönem eserlerini etkileyecek şekilde zikredildiği ancak tertibin muhkem bir şekilde teessüs etmediği sonucuna ulaşabiliriz.

İmam Şāfi'īnnin er-Risāle'si ile günümüze ulaşan ikinci eser olan Ceșșāṣ’ın el-Fuṣūl adlı eseri arasındaki yaklaşık bir buçuk asırlık dönemde şer'î kaynaklara ilişkin birtakım değerlendirmelerin yapıldı̆̆ı görülmektedir. Bu değerlendirmeleri yapan kişilerden biri Şāfiīinin akrânı da olan Mu'tezilî âlim ve edebiyatçı Cāhị (255/869) eserlerinde üç farklı yerde bir şeyin helal ya da haram olduğuna hükmedebilmek için başvurulacak kaynakları zikreder. Bunların ilkinde konuşan (nātik) kitab, üzerinde ittifak edilen sünnet, sahih akıl ve isabetli kıyas şeklinde dört kaynak bulunur. Benzer bir tasnifte de kitab, icmā', akıl ve kıyası listeler. Son tasnifinde de konuşan kitab, doğru haber, meşhur rivayetler, meseller ve doğru tecrübeleri sıralar. ${ }^{31}$

Aynı dönemde şerî̀ delillere değinen bir diğer âlim Hāris el-Muhāsibī (243/857) Kitab, sünnet, icmā, açık istinbat ve caiz olduğu yerde kıyas şeklinde beş kaynak zikreder. ${ }^{32}$ Açı istinbat ifadesiyle muhtemelen naslara dönük bir ictihad faaliyetini kastettiği görülen Muhāsibīnnin zihninde dörtlü bir tertibin olmadığı ancak bunları da kapsayacak şekilde şer’î delillere değindiği anlaşılmaktadır.

${ }^{26}$ Ebū Hilāl ‘Askerī, el-Evā’il (Ṭanța: Dāru'l-beşīr, 1408), 374.

27 Ceșșāṣ, el-Fuṣūl fi'l-ușūl, 3/271.

28 Şeybānī’nin uṣūlü dörde ayırıp bunlar arasında sahabenin icmā‘ ve ihtilafını da saydığını Ebū'l-Hüüeyin el-Bașrī de nakleder. Bk. Muhammed b. 'Alīb. Tayyib Ebū'l-Ḥuseyin el-Bașrī, el-Mu'temed fiu uṣūli'l-fiḳh, thk. Halīl Muhyiddin el-Meys (Beyrut: Dāru'l-kutubi'l-'ilmiyye, 1983), 2/366.

29 Muhammed b. İdrīs. Şāfiłīe er-Risāle, n.d., 39.

30 Şāfíī, er-Risāle, 90, 476.

31 Bk. Ebū Oșmān 'Amr b. Bahr Cāhiz, Resā'ilu'l-Cāhiz (Kahire: Mektebetu'l-hanc1, 1991), 4/277; Ebū Oșmān 'Amr b. Bahr Cāhiz, Kitābu'l-hayevān (Kahire: Mektebetu ve Matbaatu Mustafa el-Babīel-Halebī ve Evlādihi, 1965), 6/360; 7/45.

32 Ebū 'Abdillah el-Ḥāris b. Esed Ḥāris el-Muhāsibī, Māhiyetu'l-'aḳl, thk. Hüseyin El-Kuvvetli, 2. Basım (Beyrut: Dāru'l-fikr, 1398), 235. 
Bu dönemin bir diğer önemli bir siması Ebū ‘Ubeyd el-Kāsım b. Sellâm (224/838-39) da şerî̂ delillerin sadece üç tane olduğunu ifade eder. Bunları da kitab, sünnet ve büyük müctehidlerin icmā‘ ve kıyasa dayanarak ulaştıkları hükümler olarak zikreder. İctihadı bu müctehidlerin görüşleri arasında tercihte bulunmak olarak tasvir eden Ebū 'Ubeyd'in bu ifadeleri şer'î delillere bakışının yanı sıra mezhepleşme ve taklidin geçirdiği evreler bakımindan da oldukça değerlidir. ${ }^{33}$

Meşhur zahiri âlim Davūd b. 'Alī'nin oğlu Muhammed b. Davūd (297/910) ise kıyası reddeden zahiri düşünceyle mütenasip olarak şerî̀ delilleri kitab, sünnet, icmā‘ ve bağlayıcı rivayet şeklinde listeler. ${ }^{34}$ Ceș̣āș’̣n muasırlarından Şâfi'î âlim Ibnu'l-Kāṣ (335/947) şer'î delilleri duyu, akıl, kitab, sünnet, icmā', kıyas ('ibre) ve dil şeklinde yediye çıarırken, aynı dönemde yaşayan bir diğer Malikî âlim Ebū ‘Ubeyd el-Cubeyrī (378/988) ise Medine ehlinin icmā‘ın 1 da ekleyerek kitab, sünnet, icmā‘, Medine icmā‘' ve kıyas ('ibre) şeklinde beşli bir tasnif yapar. ${ }^{35}$

Yukarıda yapılan analizlerden zamanımıza ulaşan ikinci mütekamil usul eseri olarak bilinen el-Fuṣūl'e kadar olan dönemde sünni usulcüleri arasında dörtlü bir şer̂̂̂ delil tertibinin henüz te'sis edilmediği görülmektedir. Ceșșāṣ el-Fușūl adlı eserinde bu dört delili listeler, ancak şer'î deliller ifadesini kullanmaz. Bunun yerine şer'î beyanı te'sis eden kaynaklar şeklinde zikreder. ${ }^{36}$ Ceșsāș’̣’ın Davūd b. 'Alī’nin kıyasın asıl mı fer' mi olduğuna ilişkin sorusunu değerlendirdiği kısa bir bölüm gerek Davūd'un deliller ile ilişkili yerleşik bir anlayışı olduğunu göstermesi gerekse Ceșșāṣ’ın fikıh usulü tarihi boyunca kıyasın mahiyeti ile bir şer'î kaynak olması arasındaki ilişkiye dair süregiden tartışmalara netlik kazandırabilecek dikkat çekici izahı bakımından önemlidir:

"Davūd kıyasın manası hakkındaki cehaletine delalet eden bir soru yöneltti kıyas taraftarlarına: Söyleyin (kıyas) bir așıl mıdır fer' mi? Eğer așıl olsaydı üzerinde bir ihtilaf olmaması gerekirdi; yok eğer fer ' ise neyin fer'i bu?' (Ceșșāṣ cevaben) Kıyas kıyası yapan kişilerin fiilidir. Kıyası yapan kişinin fiili için bu așıldır ya da fer'dir denilmez. Tıpkı oturuşuna, kalkışına, susmasına ve hareket etmesine așıl ya da fer‘ denemeyeceği gibi... Soruyu doğru şekilde şöyle sorabilirdi: 'Söyleyin bakalım kıyas ile hükmetmenin gerekliliği yahut kıyas ile hükmetmenin câiz oluşu bir așıl mıdır fer' midir?' Bu sorunun cevabı da şudur: Kıyas kendi üzerine bina edilen bakımından așl iken; kendisi üzerine bina edildiği şey bakımından ise fer'dir. Kendisi üzerine bina edildiği asıl daha önce zikredildiği veçhile kitab, sünnet ve ümmetin icmā‘ıdır. Fer'i ise onun üzerine bina edilen çeşitli kıyasa dayalı olan hakkında nașș ya da icmā‘ bulunmayan meselelerdir." ${ }^{37}$

Ceșṣāṣ’ın, kıyasın temel bir delil mi yoksa temel delillere dayalı bir yöntem mi olduğuna ilişkin uzun soluklu tartışma henüz alevlenmeden așıl kavramının sözlük anlamına

33 Bk. Ebū Hanīfe Kāḍī Nu'mān, İhtilafu uṣūli'l-mezāhib (Beyrut: Dāru'l-Endelus, 1983), 213.

34 Bk. Kạạīi Nu'mān, İhtilafu uṣūli'l-mežāhib, 162.

35 Bk. Kāsım b. Halef Ebū 'Ubeydi'l-Cubeyrī, et-Tevassut beyne Mālik ve İbni'l-Kāāstm fi'l-mesāili'l-letī ihtelefā fihā min mesāili'l-Mudevvene, thk. Baḥu Mușțafa (Mıșır: Dāru'ẓ-ẓıyā, 2005), 212; Ebū'l-Muẓaffer Manșūr b. Muhammed es-Sem'ānī, Kavāṭi u'l-edille fi'l-uṣūl, thk. Muhammed Ḥasan Muhammed Hasan İsmā‘īl (Beyrut: Dāru'l-kutubi'l-'ilmiyye, 1999), 1/22.

36 Ceșșāṣ, el-Fușūl fi'l-ușūl, 2/31.

37 Ceș̣āṣ, el-Fuṣūl fi'l-uṣūl, 4/95. 
dayanarak bir izah getirdiği görülmektedir. Doğrusu, sonraki dönemlerde bu konuda kendisine çok dikkat çekilmemiş olsa da getirdiği bakış açısının muahhar usulcülerin kıyası bir temel şerî̀ delil olarak teorize etmelerinin önünü açacak mahiyyette olduğu anlaşılmaktadır. Delillerin sayısı ve sıralaması bakımından önceki dönemle Ceșșāṣ arasındaki temel fark, Ceșșāṣ’ın farklı sayıda kaynakları zikretmemesi ve sahabī kavli, istihsan gibi bazı başka delilleri kabul etmesine rağmen bunları deliller sıralamasını verirken saymamasıdır. Bu yönüyle dört temel şerî delilin te'sisi bakımından önemli bir yeri vardır. Bununla birlikte şerî̀ delil terimini kullanmaması ve icmâlî deliller bahsini bağımsız bir bölüm içinde işlememesiyle de geç dönem eserlerinden ayrılmaktadır. Nitekim bu konuda önemli katkılarına rağmen Ceș̣āș̣'ın sonrasındaki kaynaklarda uzun bir süre dört temel şer'î delil tertibinin yerleşmemiş olması tek başına Ceșșāș’i bu tertibin fikıh usulü literatüründe kabul görmesini sağlama noktasında temel bir rolde görmeye engel teşkil eder. Bununla birlikte bu tertibin yerleşmesinde önemli aktörler olan hicrî 5. asır Hanefî usul âlimlerine etkisi açıtır.

Nitekim örneğin, müteakip dönemde yaşamış olan Hanbelî usulcü 'Ukberī (428/1037) şer'î delaletin kitab, sünnet, icmā, kıyas, istișhābu'l-ḥāl ve sahabi kavli șeklinde altı aṣlı olduğunu iddia eder. ${ }^{38}$ Dört delil yerine altı delil zikretmesi ve şerî deliller ifadesini kullanmasa da delaletü'şer' ifadesini kullanmasıyla dikkat çeken 'Ukberī, deliller yerine asıllar (ușūl) ifadesini tercih eder.

Hicrî dördüncü asrın son usulcülerinden Bākillānī (403/1013) delil kavramını özel bir başlık altında inceleyen aḳ̂î ve vaz'î şeklinde bir tasnife tabi tutan ilk kişi olarak delil kavramının fikıh usulü metinlerinde yaygınlaşmasına katkı sağlamıştır. ${ }^{39}$ Ancak bu müstakil başlıkta delili bizim konumuzda incelediğimiz şekliyle şerî delil şeklinde değil "zorunlu olarak bilinmeyen bir şeyin bilgisine üzerinde doğru bir akıl yürütmeyle ulaştıran şey" şeklinde kelamcıların kullandığı geniş anlamıyla ele almıştır. Şer'î delil yerine döneminin fikıh uṣulü terminolojisini takip ederek ușūl terimini kullanmayı tercih etmiştir. Asıllar arasındaki tertip konusuna özel bir önem veren ve kitabının başlıklarını da buna göre tasnif eden Bākillānī bu asılları, hitāb (kitab ve sünnet), peygamberin fiilleri, haberler, icmā', kıyas, mufti ve mustefïnin sıfatı ve haẓr ve ibāḥa şeklinde sekiz başlık altında değerlendirir. ${ }^{40}$ Bununla birlikte eserinin birkaç yerinde edilletu'ş-şer' ifadesini -sistematik olmasa da- kullanmış ve sonrasında gelen kelamcı usulcüler için bu ifadenin terimleştirilmesinde muhtemel kaynaklardan biri olmuştur.

Hayatının büyük bir bölümünü hicrî dördüncü asırda bir kısmını da beşinci asırda geçirmiş olan ve kelamcı-usul literatüründe önemli bir yeri olan Ḳādī 'Abdulcabbar'ı da (415/1025) usul eserlerini dördüncü asırda kaleme alması nedeniyle burada zikredebiliriz. Ḳādī ‘Abdulcabbar Şerḥu ușūli’l-hamse adlı eserinde nelerin delil olacağı sadedinde akıl, kitap, sünnet ve icmā’ şeklinde dört delil sayar. Sonrasında muhatabının neden kıyas ve

38 İbn Şihāb el-‘Ukberi, Risāle fi ușūli'l-fiḳh, thk. Muvaffaḳ b. 'Abdillāh b. 'Abdilkādir (Mekke: el-Mektebetu'lMekkiyye, 1992), 47.

39 Ebū Bekr Muhammed b. Ṭayyib b. Muhammed Bāḳıllānī, et-Takrïb ve'l-irşād (es-șagīir), thk. ‘Abdulhamīd b. 'Alī Ebū Zuneyd, 2. Basım (b.y.: Mu'essesetu'r-risāle, 1998), 2/202-210.

40 Bāḳllānī, et-Takrīb ve'l-irşād, 1/310-315. 
haber-i vâhidi bu deliller arasında zikretmediği sorusuna ise öğrencisi Ebū'l-Huseyn elBașrỉnin delili kat‘ alanına emareyi ise ẓann alanına ilişkin kabul eden ikili tasnifi ile değil; kıyas ve haber-i vâhidin esasında diğer dört delilde içkin olmasıyla cevap verir. ${ }^{41}$

Son olarak bir sonraki asırdan itibaren delil kavramını kat î bilgiye götürücü olarak tanımlayan anlayışın bu asırdaki öncü temsilcilerinden biri olarak sayılabilecek İbn Fūrek (406/1016) burada anılabilir. İbn Fūrek ilk fikıh usulü ve kelam sözlüğü sayılabilecek eserinde ușūlu'l-fiḳhı “Açı bir şerî̀ hükme götüren her bir kat'îş̧erî̀ delil” şeklinde tanimlar. ${ }^{42}$

\section{Hicrî 5. Asır: “Şerî Delil” Terimleşmesi (Üç Artı Bir Delil Tertibi ve Aṣl/Ma'kūlu’l-Aṣl Ayrimi)}

Hicrî beşinci asrı şer'î delillerin tertibi bakımından üç artı bir delil asrı olarak tanımlarsak insaflı bir genelleme yapmış oluruz. Bu asrın en önemli gelişmelerinden biri şer $\hat{1}$ delil ifadesinin terimleşmesi ve daha önce kullanılagelen alternatif kavramların yerini almaya başlamasıdır.

Bu dönemde yaşamış Mu'tezilî usulcü Ebū'l-Ḥuseyn el-Bașrī (436/1044) “şer'î deliller" (el-edilletu'ş-şer'iyye) terkibini eserinde sıklıkla kullanan ilk isim olarak ortaya çımıştır. Her ne kadar kendisinden önce Bāḳıllānī, en-Nāțik bi'l-ḥaḳk, Kāại ‘Abdulcabbar gibi usulcüler delil kavramının fikıh usulünde kullanımının yerleşmesine katkı sağlamışsa da geç dönem fikıh usulü literatüründe yerleşik haliyle şer'î deliller şeklindeki terkip ilk olarak el-Mu'temed'de görülmektedir. Bu nedenle bize ulaşan literatür içerisinde, fikıh usulü eserlerinde öncel ușūl şeklinde ifade edilen kaynak ve yöntemlere şerî̀ deliller adı verilmesinde en etkili ismin Ebū'l-Huseyn el-Bașrī ve çalışmanın da onun eseri el-Mu'temed olduğu anlaşılmaktadır.

Delillerin tertibi ile ilgili olarak ise Ebū'l-Ḥuseyn el-Bașrī “şer'î delìl” terimini kullanarak kitab, sünnet, icmā, kıyas şeklinde bir sıralama vermesiyle temel şerî delillerin dörtlü şekilde te'sisine de önemli bir katkı sağlamıştır. ${ }^{43}$ Bununla birlikte delil kavramının esasında ancak kat‘ī olanı kapsaması gerektiğini öne sürerek kitab, sünnet ve icmā‘ deliller arasında zikretmiş, haber-i vahid ve kıyası ise emare şeklinde tanımlayarak dörtlü tasniften feragat etmiştir. ${ }^{44} \mathrm{O}$ nedenle Bașrīyi "şerî deliller" terkibini ilk olarak sistematik bir şekilde kullanan usulcü olarak kabul edebilirsek de bu şerî delillerin kitab, sünnet, icmā‘ ve kıyas şeklinde dört unsur şeklinde tasnif ettiğini söyleyemeyiz.

Ebū'l-Ḥuseyn el-Bașrìnnin Semerkand bölgesinden bir çağdaşı olan ve Hanefî usulünün kurucu isimlerinden kabul edilen Ebū Zeyd ed-Debūsī (430/1039) eserine Takvimu'ledille ismini vermesine rağmen söz konusu icmâlî delilleri "el-hucecu'ş-şer'iyye" isimlendirmesiyle anmayı tercih eder. Bunda kendisinden önce gelen Hanefî usulcülerden ‘İsā b. Ebān ve Ceș̣̣āṣ’’ın etkili olduğunu söyleyebiliriz. ‘'̇sā b. Ebān'a atfedilen el-Hucec'ul-kebìr ve

${ }^{41}$ Ebū'l-Hasen b. Ahmed Kāāī ‘Abdulcabbar, Şerḥu uṣūli'l-hamse, thk. 'Abdulkerim ‘Osmān, 3. Basım (Kahire: Mektebetu Vehbe, 1996), 88.

42 Ebū Bekir Muhammed İbn Fūrek, el-Hudūd fìl-uṣūl, thk. Muhammed Süleymani (Beyrut: Dāru'l-ġarbi'lİslāmī, 1999), 139.

43 Ebū'l-Huseyin el-Bașrī, el-Mu'temed, 1/402; 2/123.

${ }_{44}$ Ebū'l-Huseyin el-Bașrī, el-Mu'temed, 2/239. 
el-Ḥucecu's-sagīir usul eserleri başlıklarından ve kendisine yapılan sonraki eserlerdeki atıflardan ve Ceșsāș’̣n da bu delillerden bahsederken huccet terimini tercih etmesinden bu çıkarımı yapabiliriz. Nitekim Debūsīnnin sonrasında gelen Serahsī ve Pezdevīnnin de aynı terimleri sürdürmesi Hanefî usulünün kuruluş döneminde icmâlîdeliller için bu terimin baskın olduğu sonucuna bizi götürmektedir. Seraḥsī ve Pezdevī de şerî hüccetlerdeki asılların (sırasıyla el-uṣūl fìl-huceci'ş-şer iyye ve ușūlu'ş-şer') kitab, sünnet ve icmā' şeklinde üç olduğunu ancak kıyasın bu asıllardan istinbat edilen dördüncü bir asıl olduğunu ifade eder. ${ }^{45}$

Ebū'l-Ḥuseyn el-Bașrī ile başlayan delil kavramını üç kaynakla tahdid etme eğiliminin aynı asırda yaşamış Şâfîî, Eş‘arî, Mâlikî ve Hanefî usulcülerde yankı bulduğu görülür. Şâfi îlerden Ḩațīb el-Bag̉dādī (463/1071) ve Şirāzī (476/1083); Eş‘arî usulcülerden Cuveynī (478/1085) ve öğrencisi Ġazāīi (505/1111); ${ }^{46}$ Hanefîlerden Serahsī (483/1090) ve Pezdevī (482/1089) usul yahut edille şeklinde ifade ettikleri delillerin sayısının üç olduğunu ifade eder. Ancak kıyası ve istidlāl, istiṣhāb gibi ilave bazı unsurları bir biçimde bunlara ilhak ederler. Ancak bu noktada Seraḥī ve Pezdevīnnin ifadelerini diğerlerinden açık bir biçimde ayırmak gerekir. Zira her ne kadar üç delili ayrı bir biçimde ifade etseler de kıyası hemen ardından "dördüncü delil” olarak zikrederler. Bu daha sonraki dönemlerde neden bu şekilde dört delil tertibinin Sem‘ānī, Rāzī gibi usulcüler tarafından fakihlere atfedildiğini anlaşlır hale getirmektedir. Bir başka ifadeyle Ceșșāṣ ile başlayan dört delile doğrudan işaret etme eğilimi Hanefî usulcülerin geliştirdiği bir tertip sıralaması gibi görünmektedir.

Kıyası, kitab, sünnet ve icmā'dan ayrı bir biçimde așıl ve ma'kūlu'l-aṣl şeklinde tasnif edenler arasında Şâfiî̂ usulcüler önce çıksa da Mâlikî usulcü Bâcî(474/1081) de bu kategorizasyonu takip eder. Ḩațīb el-Bag̉dādī fikhın kendileri üzerine bina edildiği deliller şeklinde ifade ettiği fikhın asıllarını (ușūlu'l-fiḳh) kitab, sünnet ve icmā olarak zikreder ve kıyası daha sonra işleyeceğini ifade eder. ${ }^{47}$ Benzer şekilde Şâfi î usulcüsü eş-Şirāzī de usul ile delillerin asılları (ușūlu'l-edille) olan kitab, sünnet ve icmā‘ın; ma‘kūlu'l-aṣl ile ise bunların dışında kalan kıyas, delīlu'l-ḩitāb, fahvāl-ḩitābın kastedildiğini ifade eder. ${ }^{48}$ İmam Şāfiī'nin terminolojisindeki ma'nā kavramı Bag̉dādī ve Şirāzī gibi âlimlerin dilinde ma'ḳūlu'l-aṣl terimleștirmesine kaynaklık ederken; ilk olarak Cuveynī'de görülen sonraki asırlarda mantık diliyle yeniden usulü yorumlayan Āmidī ve Ibnu’l-Ḥācib gibi Eş‘arî usulcülerin dilinde ise kitab, sünnet, icmā‘ ve kıyas dışında kalan delillerin üst başlı̆̆ı anlaminda istidlāl kavramına dönüşecektir.

45 Muhammed b. Aḥmed b. Ebī Sehl Şemsu'l-eimme es-Serahssī, Ușūlu's-Serahsī, thk. Ebû'l-Vefā el-Efgānī (Beyrut: Dāru'l-ma'rife, 1973), 1/279; 'Alāuddīn 'Abdulazīz b. Aḥmed 'Abdul'azīz el-Buhārī, Keşfu'l-esrār Şerhu Ușūili'l-Pezdevī (b.y.: Dāru'l-kitābi'l-islāmiyye, n.d.), 1/19-20.

46 Burada hem Eş'arî hem Şâfi'î olan usulcüler arasında usul geleneğine aidiyet bakımından yapılan ayrım için bk. Ahmet Temel, "Was There a Zaydī Ușūl al-fiqh? Searching for the Essence of Zaydī Legal Theory in the First Complete Ușūl Work of Zaydīs: al-Nātiq bi-l-haqq's (340-424/951-1033) 'al-Mujzī fì uṣūl alfiqh,"' Insan \& Toplum Dergisi (The Journal of Human \& Society) 6/1 (June 3, 2016 ),72.

47 Ebū Bekir Ahmed b. 'Alī b. Sāait b. Ahmed b. Mehdī el-Hुațīb el-Bag̉ḍādī, el-Fakīh ve'l-mutefakkih, thk. Ebū 'Abdurraḥman Ādil b. Yūsuf El-Ġarrāzī, 2. Basım (Suudi Arabistan: Dāru İbnu'l-cevzī, 2000), 1/192.

48 Cemāluddīn İbrāhim b. 'Alī b. Yūsuf Ebū İsḥāk Şīrāzī, el-Luma fì uṣūli'l-fiḳh (b.y.: Dāru'l-kutubi'l-'ilmiyye, 2003), 103. 
Cuveynī sem‘ī deliller (el-edilletü's-sem'iyyāt) ifadesini kullanarak kitab, sünnet ve icmā'ı zikreder ve Ebū'l-Ḥuseyn el-Bașrīnnin delili kat' alanına inhisar eden izahına benzer bir şekilde, bazılarının bunlara haber-i vahid ve kıyası eklediğini ancak bunun isabetli olmadığını ifade eder. ${ }^{49}$ Ancak aynı zamanda bu temel deliller (uṣūl) arasında saymamakla birlikte istidlāli bu delillere dayalı olmak kaydıyla, Şāfiı̄nnin ma‘nā kavramına da atıfla, maslahata dayalı olarak bir hükme ulaşma yolu olarak kabul eder. ${ }^{50}$ İstișhāb deliline istidlāl konusunu işledikten sonra kısa bir başlıkla değinmesi ve birkaç istisna dışında istișhāba dayalı hüküm vermeye eleştiriler yöneltmesi kendisinden sonra gelecek Eş‘arî-Şâfiīi usulcülerden ayrıldığı bir noktadır.

Ġazālī de el-Mustașfä̀nın başlarında kitab, sünnet ve icmā‘n hükümlerin delilleri (edilletu'l-aḥkām) olduğunu ifade ederken; ${ }^{51}$ müstakil olarak deliller bahsine başladığında ise bunlara ek olarak ve bu delillere ait bir kaynak olmadığı durumda ispat için değil nefy (hükmün olmadığını anlamak açısından) için "akıl delili ve istișhābı” da zikrederek dört delil olduğunu söyler. ${ }^{52}$ Kıyası bir hüküm istinbāț metodu olduğu gerekçesiyle bu deliller arasında zikretmez.

Bir önceki nesilde Hanbelî usulünü temsil eden ‘Ukberī'den önemli ölçüde etkilenen Hanbelî usulcü Ebū Ya‘lā el-Ferrā (458/1066) şer'î delilleri sıralarken 'Ukberīnin ifadelerini "kendisiyle beyanın ortaya çıktığı" (mayaka'u bihil beyān) şeklinde kelimesi kelimesine muhafaza ederken, delillerin sayısını altı değil dört olarak kitab, sünnet, icmā, kıyas şeklinde verir. ${ }^{53}$ Geç bir akranı olması hasebiyle aralarında böyle bir fark olması, şerî delillerin dörtlü tertibinin terimsel olmasa da sayısal olarak Hicrî beşinci asırla kristalleşmeye başladığının göstergesi olarak kabul edilebilir. Hicri beşinci asırda Şâfî̂ ve Hanefî usulcüler her ne kadar usul ifadesi kullanarak üç delili zikretse de bunlara ek olarak kıyasa da atıf yaparak dörtlü tertibin oluşmasına katkı sağladıkları görülmektedir. Nitekim konuyu aydınlatan bir tasvir sunması ve "ușūlü (delilleri)" dört olarak kabul etmesiyle Sem‘ānī (482/1089) Şâfi îler arasında bu asırda bir dönüm noktasıdır. Her ne kadar imamı Şāfiı̄’nin ma‘nā kavramsallaştırmasına dayandırılarak yapıldığını söylediği aṣıl ve ma'kūlu'l-aṣl şeklindeki ilk üç delil ile kıyas arasında yapılan ayrıma işaret etse de ${ }^{54}$ Sem‘ānī "fukahanın büyük çoğunluğunun kabul ettiği üzere" daha sahih taksimin "dört uṣūl” şeklinde olduğunu ifade eder. Hicrî beşinci asrın sonlarında vefat ettiğine göre, Sem‘ānīnnin tanıklı̆̆ını dikkate aldığımızda şerî̂ ușūlün -henüz edille-i şer'iyye kullanımı yerleşmemiş olsa da- kitap, sünnet, icmā‘ ve 'ibret (kıyas) olduğuna dair çoğunluk görüşünün bu asırda artık şekillenmiş olduğunu rahatllkla söyleyebiliriz. ${ }^{55}$

49 İmāmu'l-Ḥarameyn el-Cuveynī, el-Burhān fi uṣūli'l-fiḳh, thk. Șalāh b. Muhammed b. 'Aveyde (Beyrut: Dāru'l-kutubi'l-'ilmiyye, 1997), 1/33.

50 Cuveynī, el-Burhān, 2/162.

51 Huccetu'l-İslām Ebū Hāmid Muḥammed b. Muḥammed el-Gazzālī, el-Mustașfā fì 'ilmi'l-uṣūl, thk. Muhammed 'Abdusselām ‘Abduşşāfī (Beyrut: Dāru'l-kutubi'l-'ilmiyye, 1993), 6.

52 Gazzālī, Mustașā, 80.

53 Muḥammed b. Ḥuseyn b. Muhammed b. Hualef Ebū Ya'lā el-Ferrā', el-‘Udde fì ușūli'l-fikh, thk. Ahmed b. 'Alī el-Mubārekī, 2. Basım (b.y.: yy., 1990), 1/110.

54 Sem'ānī, Kavāți u'l-edille fi'l-ușūl, $1 / 22$.

55 Sem‘ānī, Kavāți u'l-edille fi'l-ușūl, 1/22. 


\section{Hicrî 6. ve 7. Asırlar: Şerî́ Delillerin Dörtlü Tertip Üzere Kabul Görmesi}

Bu dönemde kitab, sünnet ve icmā'ı nașṣ kapsamında aṣl; kıyas ve istidlali ise fer ' ya da ma'kūlu'l-aṣl şeklinde bir ayrım dahilinde tasnifeden Āmidī $(631 / 1234)^{56}$ ya da Vercelānī gibi usulcüler varsa da hicri altıncı asırda artık kıyasın delil terimi kapsamında zikredilmeye, dört asıl şeklinde tertibin yaygınlaşmaya ve şerî́ delil terminolojisinin rafine hale gelmeye başladı̆̆ı görülmektedir. Örneğin Fahreddīn er-Rāzī (606/1210) tefsirinde fakihlerin şeriatın asıllarının (ușūlu'ş-şerì‘a) kitab, sünnet, icmā‘ ve kıyas şeklinde dört olduğunu iddia ettiğini (zatamu $)$ ifade eder. ${ }^{57}$ Usul eserinde bu tertibi müstakil bir başlık altında zikretmese de şer ${ }^{i}$ hükmün ancak "nașș, icmā‘ ya da kıyasla temellendirilebileceğini tasrih etmesi bu tertibi benimsediğine işaret eder. ${ }^{58}$ Müstakil bir başlık içinde zikretmiyor oluşu; Rāzìnin bu tertibi fukahaya atfetmesiyle ilgili olmalıdır. Yukarıda da geçtiği üzere, Sem‘ānī’nin Şâfîî usulcülerin aṣl ve ma‘kūlu'l-așl şeklindeki tertibini zikredip fakihlerin kitap, sünnet, icmā‘ ve kıyas şeklinde tertibini benimsemeye meyletmesi aynı sebeptendir. Bilindiği üzere Sem‘ānī Eş‘arî usulüne meyleden Şâfił îleri tenkit ederek fakih-usulcülerin ekseninde fikıh usulü telifinde bulunmuştur. Rāzỉnin tefsirde işaret ederek ayetle temellendirdiği ve usul eserinde atıfta bulunduğu fukahanın dörtlü tertibinin, fikıh usulü yazımında Ġazālīyi takip eden mantık yönelimli usulcüler arasında kabul görmesinde etkili olmuştur. Fıkıh usulü yazımında kendisini takip eden, Tuncay Başoğlu'nun Rāzī mektebi dediğ ${ }^{59}$ geleneği oluşturan isimlerden örneğin Beyḍ̄̄vī (685/1286) bu tertibi açıkça el-Minhāc'ın başında zikreder. ${ }^{60}$

Mantık dili ile usul yazımının diğer bir temsilcisi Âmidī ise üç artı iki şeklinde beşli bir delil tasnifi yapar. Önce delili aklî ve şer'îşseklinde ayırır; sonra şer'î delili sahih olan ve olmayan şeklinde ikiye ayırır. Sahih olan delilleri de sebr ve taksim ile sahip oldukları sıfatlara göre hiyerarşik olarak beş delil şeklinde ifade ettikten sonra nașșlar ve icmā‘ın aslî; kıyas ve istidlâlin ise bunlara tâbi olarak fer'îolduğunu ifade eder. Sahih olmayan deliller arasında da şer'u men ḳablenā, șaḥābī ḳavli, istiḥsān ve mașlaḥat-ı mürseleyi zikreder. ${ }^{61}$ Āmidìnin Cüveynî den ödünç aldığı ancak yeniden yorumladığı istidlāl terimi burada dikkat çekicidir. Cuveynīnin kullanımında maslahata tekabül eden istidlāl; Āmidī'de ise kitab, sünnet, icmā‘ ve kıyasın dışında olan her delili kapsayan bir şemsiye kavram olarak tarif edilir. İstidlāli, ne olduğuyla değil ne olmadığıyla tanımlamasına gelecek muhtemel eleştirilere cevap sadedinde de Āmidī, esasında hiyerarşik olarak kendisinden daha güçlü ve açık olan şeylerle istidlāli tanımlamış olduğunu iddia ederek ikna edici olmayan bir açıklama yapar. ${ }^{62}$ Daha sonraki açıklamalarında sebeb, şarț, māni', istișhāb, iḳtirān kıyası ve istiṣnā kıyasını içeren, bir

\footnotetext{
56 Āmidī, el-ìhkām, 1/158.

57 Ebū ‘Abdillāh Muhammed b. ‘Ömer b. Huseyn Faḩreddīn er-Rāzī, el-Maḥsūl, thk. Tāhā Cābir Feyyāż el'Alvānī, 3. Basım (Riyad: Mu'essesetu'r-risāle, 1997), 1/40; Rāzī - Ebū 'Abdullāh Muhammed b. 'Omer b. el-Ḥasan b. el-Ḥuseyn et-Teymī er-Rāzī.el-Mulakkeb Bi Faḥruddīn er-Razī, Mefātīhu’l-ġaybet-tefsīru'l-kebīr (Beyrut: Dāru İhya' et-Turās el-'Arabī , 1420), 10/112.

58 Fahreddīn er-Rāzī, el-Mahsūl, 6/168.

59 Bk. Tuncay Başoğlu, Fıkı h usulünde Fahreddin er-Razi mektebi, 2. Basım (İstanbul: İSAM Yayınları, 2014).

60 Nāṣiru'ddīn el-Beyḍ̄āī, Minhācu'l-wușūl ilā 'ilmi'l-ușūl, thk. Şaban Muhammed İsmail (Daru ibn Hazm, 2008), 51.

61 Āmidī, el-ïhkām, 1/158-159.

62 Āmidī, el-ìhkām, 4/118.
} 
hükmün başka bir hükmü zorunlu kılması anlamına gelen telazümü kastettiği anlaşılmaktadır. Bir başka ifadeyle, Āmidī, mantık yoluyla elde edilen bir takım aklî çıkarsamaların fikıh usulünde doğrudan karşılı̆̆ı olmadığından istidlāl terimi ile bunları fikıh usulü alanına dâhil etmiştir.

Öyle görünüyor ki Hanefî usulcüler arasında icmâlî deliller için huuccet yerine delīl terimleştirmesinin baskın hale gelmeye başlamasında geçiş sürecinde olan isimler Lāmişī (VI./XII. asrın ilk yarısı), Semerḳandī (539/1144) ve Usmendī (552/1157) gibi isimler olmuştur. Semerkandī, Debūsīnnin izinde bu icmâlî delillere delā’il ve el-edilletu'ş-şer'iyye ifadelerini kullanmışsa da seleflerinin terminolojisini takip ederek çoğunlukla huccet terimini tercih etmiştir. ${ }^{63}$ Usmendī delil ve emare terimlerini kullanmakla birlikte huccet terimini eseri boyunca daha sıklıkla tercih etmiştir. ${ }^{64}$ Her ne kadar metnini usulünü esas alarak üreten Ahsikesī (644/1246) ve en-Nesefī (710/1310) Pezdevīnin üç artı bir şeklindeki delil tasnifini sürdürse de İbnu's-Sā'ātī (694/1298) ile birlikte bu deliller artık Hanefî usulcüler tarafindan hem "el-edilletu'şer 'iyye" isimlendirmesiyle anılır olmuş hem de başkaca bir tasnife gitmeksizin bunların kitap, sünnet, icmā‘ ve kıyas şeklinde dört olduğu da genel kabul görmüştür. ${ }^{65}$

Dört delil için şer $\hat{i}$ asıllar ifadesi yerine şer $\hat{i}$ hükümlerin delilleri (edilletü ahkāmi'şer'iyye), şer'î deliller (edilletü’ş-şer') şeklindeki ifadelerin ise Ibnu'ș-Ṣalāh eş-Şehrezūrī (643/1245), ‘'̇zz b. ‘Abdisselam (660/1262), Karāfí (684/1285) gibi âlimlerin eserlerinde hicri yedinci asırda iyiden iyiye yerleștiği görülmektedir. ${ }^{66} \mathrm{Bu}$ dönemin ardından sünni fikıh usulü literatüründe, "imamlar arasında" yahut "dört mezhep arasında" ittifak edilen “dört delil” şeklindeki tertibin yerleşik hale geldiği görülmektedir.

\section{Hicrî 8. Asır ve Sonrası: El-Edilletu'l-Erba‘a}

Bu asırda önceki dönemde artık yerleşmiş hale gelen şer'î delillerin dört unsurdan ibaret olduğu anlayışı yeni bir isimlendirmeyi de artı doğurmuştur: el-edilletu'l-erba‘a. İlk olarak Șadru'ş-şerīa'nın (747/1346) et-Tavdịh’’inde gördüğümüz bu terimleştirme ondan sonra et-Telvịh ve onun haşiyeleri üzerinden literatürde etkili olmuştur. ${ }^{67}$ Ancak akranları arasında Ebū'ś-Senā el-İșfahānīnin (749/1349) de bu terimi kullanıyor olması tek başına Șadru'ş-şerīa'nın bu terimleştirmeyi gerçekleştirmediğini gösterir. Āmidì’yi takip ederek kitab, sünnet, icmā', kıyas ve istidlâl şeklinde beş delil zikreden İbnu'l-Hāạib'in

63 Bk. Alāu'd-dīn Ebū Bekir Muhammed b. Ahmed es-Semerḳandī, Mīzānul'-uṣūl fì netāici'l-'ukūl, thk. Muhammed Zekî ‘Abdilberr (Katar: Mațâbi'u’d-Dûha'l-hadîse, 1984), 69; 683.

64 Alāeddīn el-Usmendī, Bezlu'n-naẓar, thk. Muhammed Zeki Abdülberr (Kahire: Mektebetu't-turās , 1992), 5-10.

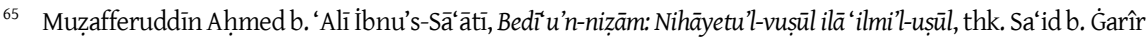
b. Mehdî es-sulemî (Mekke: y.y., n.d.), 1/235.

${ }^{66}$ Ebū 'Abbās Şehābeddīn Ahmed b. İdrīs Karāfī, el-Furūk envār'ul-burūkfi envāi'l-furūḳ, thk. 'ālem’ul Kutub (b.y.: y.y., n.d.), 1/49; Ebū Amr Takiyyuddīn İbnu'ș-Ṣalāḥ, Edebu'l-muftī ve'l-musteftī, thk. Muvaffak Abdulkadir (Medine: Mektebetu'l-'Ulūm ve'l-Hikem, 2002), 86; Ebū Muhammed 'İzzeddīn b. 'Abdusselām, Kavāiidu'l-aḥkām fi meșālihil'-enām, thk. Țāha Abdurraūf Sa'id (Kahire: Mektebetu el-kulliyāti'lezheriyye, n.d.), 1/10.

67 'Ubeydullah b. Mes'ûd el-Mahbûbî Șadru'ş-şerī'a, et-Tavdīh fi halli ġavāmiḍitt-tenkịh (Telvīh içinde) (y.y: Mektebetu Sabīh bi-Mișr, n.d.), 1/21. 
(646/1249) Muhtașaru'l-muntehā'sına yazdığı şerhde İṣfahānī bu sıralamayı "edille-i erba'adan sonra istidlâli zikretmek" olarak ifade eder. ${ }^{68}$ Hâlbuki bu sıralamanın kaynağ olan Āmidī’nin aslî ve fer'î deliller taksimi üzerinden üç artı iki şeklinde bir tertibi öne sürdügünü yukarıda görmüştük. Hanefî usulünde İbnu's-Sā‘ātī ile başlayıp Șadru'ş-şerīa ile terimleşerek devam eden şer'î delilleri kitap, sünnet, icmā‘ ve kıyas şeklinde sıralayan dörtlü tertip sonraki Hanefî usul eserlerinde norm haline dönüşmüştür. Nitekim İbn Melek (821/1418'den sonra) Menār şerhinde neden kıyasın ayrı bir şekilde tasnif edildiğine ilişkin soruya cevap verme ihtiyacı hisseder. İlk üç delilin hem fikıh hem kelam için delil olması, kıyasın ise sadece fikıh için delil olmasıyla; kıyasın ilk üç delilden teferru' etmesiyle ve kat î olmamasıly bu durumu izah eder. Daha sonra da muhtemel itirazları kendisinden dört asır önce yaşamış olan Ceșșāș’ın kıyasın üç delile göre fer‘ ondan ulaşılan hükme göre aṣl olduğuna dair argümanını çağrıștıran bir biçimde cevaplar ve nihayetinde bunun delil tertibi bakımından dört delil anlamına geldiğini zikrederek sözünü bitirir. ${ }^{69}$ Buna karşın İbn Melek'in erken bir çağdaşı Menār’ ihtisar eden İbn Habỉb el-Ḥalebī $(808 / 1406)^{70}$ ve sonrasında bu muhtasarın şârihi İbn Kutlubug̉a (879/1474) Nesefïnin sözlerine adeta sansür uygulayarak delillerin üç olduğuna ilişkin sözünü zikretmeden delilleri dört delil olarak sıralarlar. ${ }^{71} \mathrm{Bu}$ şekilde bir lafzî tasarrufa gitmeyen Hanefî usulcüler ise üç artı bir şeklinde şerî delilleri zikretmeye izah getirme geleneğini muhafaza etmiştir. Nesefỉnin Muntehab şerhinde bizzat kendisinin başlattığı kıyasın ayrı zikredilmesine çeşitli izahlar getirme geleneği Menār üzerine yapılan çalışmalarda İbn ‘Abidīn'e (1252/1836) kadar sürmüş görünmektedir. ${ }^{72}$

Hanefî usulündeki sürecin diğer usul gelenekleri için de aynı șekilde işlediğini tam olarak söyleyemesek de bu usul geleneklerinde de hicrî 8 . asrın dörtlü şerî delil tertibinin yerleşmesinde önemli bir zaman dilimi olduğu anlaşılmaktadır. Örneğin bu asrın başlarında yaşamış olan Hanbelî usulcü Katịīì (739/1338) Ġazālī etkisinde kitab, sünnet, icmā‘ (bu üçünden kıyas ve istidlālin teferru' ettiğini de söyleyerek) ve berā'et-i żimmete işaret eden istișhābu'lhāl anlamında akıl olmak üzere dört delil olduğunu söyler. ${ }^{73}$ İbn Teymiyye ve İbnu'l-Kayyim dört delile sıklıkla işaret etseler de Hanbelî usulcüler arasında bu asırda şerî delilleri kitab, sünneti, icmā‘ ve kıyas tertibiyle dört temel şerî delil şeklinde ilk teorize eden İbn Muflih'dir (763/1362).$^{74}$ Sonraki Hanbelî usulcüler de büyük ölçüde bu tertibi muhafaza eder.

68 Maḥmūd b. 'Abdurraḥmān el-İṣfahānī, Beyānu'l-muhtaṣar, thk. Mahmud Muzhir Beka (y.y.: Dāru'lMedenī el-Muessesetu's-Su'ūdiyye bi-Mișra, 1986), 3/249.

69 İbn Melek, Şerhu menāri'l-envār, tıpkı bsk. (Beyrut: Daru'l-Kutubi'l-'ílmiyye, 1308), 6-7.

70 Menār şerhi değil; Menār'ın Ebū'l-'İzz İbn Ḥabīb el-Ḥalebīnnin (Ṭāhir b. Ḥasan) tarafindan yapılan muhtasarın şerhidir.

71 Țāhir b. el-Ḥasan İbn Ḥabīb el-Ḥalebī, Muhtașaru'l-menār (İstanbul: Süleymaniye Kütüphanesi, Kadızade Mehmed, 550), 1b; Zeynuddin̄ İbn Kutlūbugāā, Hulāșatu'l efkar şerḥu Muhtasāri'l-Menār, thk. Hafiz Senāullah ez-Zāhidī (b.y.: Daru ibn Hazm, 2003), 24.

72 Krș. Muhammed Emīn İbn ‘Ābidīn, Nesemātu’l-eshār, 3. Basım (Karaçi: İdaretu'l-Kur'ān ve'l-Ulumi'lİslāmiyye, 1997), 10; Ebu'l-Berekāt Ḥāfiẓuddīn 'Abdullah b. Aḥmed b. Maḥmūd en-Nesefī, Şerḥu’lmuntehab, thk. Salim Öğüt (İstanbul: y.y., 2003), 16-17.

73 Șafiyyuddīn el-Kāțiīi, Kavā'idu'l-ușūl ve mekāi idu'l-fușūl, eds. Enes b. 'Ādil; - Abdülaziz b. Adnān (Kuvet: Dāru'r-rekā'iz, 2018), 66.

74 Ebū 'Abdillah Şemsuddīn Muhammed İbn Muflīh, Ușūlu'l-fiḳh, thk. Fehd b. Muhammed es-Sedhān (b.y.: Mektebetu ‘Abyikān, n.d.), 1/306. 
Bu asrın başlarında yaşamış Mâlikî usulcülerinden İbn Cuzey el-Kelbī (741/1340) eserinin başında delil ve emâre ayrımı yaparak kat'î bilgi ifade eden delillerin kitab, sünnet ve icmā'’dan ibaret olduğunu söyler. ${ }^{75}$ Ancak hükümlerin delilleri şeklindeki müstakil başlık altında delilleri önce nașṣ, naḳlu mezheb ve istinbāț şeklinde üçe ayırır. Nașșı kitab ve sünnet; naḳlu mez̧hebi icmā‘ ve șahābī ḳavli; istinbātı ise kıyas ve benzeri deliller oluşturur. Kıyas benzeri deliller ile yirmi delil zikreder. ${ }^{76}$ Bu asrın ikinci yarısında te'lifte bulunmuş olan, furu fikıhta Mâliki mezhebi müntesibi olan ancak usulde kendine has bir te'lif tarzı geliştiren Şāṭibī (790/1388) icmâlîşer î delillerin kitap, sünnet, icmā‘ ve kıyas şeklinde dört olduğunu ifade eder. ${ }^{77}$

\section{Sonuç}

Dört temel şerî delilin kitap, sünnet, icmā‘ ve kıyas şeklinde hicri ikinci yüzyılın sonlarından itibaren usul çalışmalarında zikredilmeye başlandığı ancak yerleşik hale gelmesinin uzun bir zaman aldığı görülmüştür. Şer'î delil terimini karşılamak üzere uzunca bir dönem hüccet, asıl gibi yer yer farklı kavramların kullanıldığı, Ebü’l-Huseyn el-Bașrīnnin ilk kez "şerî deliller" terimleştirmesini istikrarlı bir biçimde kullandığı ancak bu kullanımin usul eserlerinde nispeten uzun bir zaman sonrasında kelamci-usulcülerin etkisiyle baskın hale geldiği görülmektedir.

Fıkıh usulü tarihinde uzun bir süre şer'î delillerin tertibinde dikkate alınan temel ayırt edici nokta delillerin kat"'î ya da zannî oluşuyla ilgili ayrım olmuştur. Bu nedenle delilleri kitab, sünnet ve icmā‘ ile sınırlandırıp kıyas ve diğerlerini bunlardan ayrı tutma eğilimi uzun bir süre baskın olmuştur. Ancak hicri beşinci yüzyılda fakih-usulcülerin kullanımı sebebiyle dört şerî̂ delil tertibinin sünni fikıh usulünü domine etmeye başladığını esSem‘ānīnnin ifadeleri açık bir biçimde gösterir. Bu noktada da her ne kadar üç artı bir şeklinde bir formülasyon çerçevesinde de olsa Hanefî fakih-usulcülerin kıyası temel bir delil olarak konumlandırmaları önemli bir etki yapmış olmalıdır. Burada Fakih-usulcülerin delillerin tertibinde kat'-ẓann ayrımından ittifak edilen ve ihtilaf edilen deliller ayrımına yönelmesinin etkili olduğunu söyleyebiliriz. Bu da sünnî fikı mezheplerinin dört mezhep şeklinde yerleşik hale gelmesiyle eş zamanlı olmuştur.

Fakih-usulcülerin tertibinin yaygınlık kazandığını bazı mütekellim-usulcülerin kendi usulünde mütekellim-usul geleneğinin delil-emare tertibini sürdürmeye çalışırken; bir başka eserinde fakih-usulcülerin tertibine destekleyici bir anlatımla atıfta bulunmak durumunda kalmasında görebiliriz. Bu noktada en bariz örneklerden biri er-Rāzī'dir. Hicri altıncı yüzyılda bu dörtlü tertibin kullanımının sıklaştığı; yedinci asır itibarıyla da bugün de kullanmakta olduğumuz "aslî şerî̂ deliller" ifadesiyle bu dört delile işaretin yerleştiği anlaşılmaktadır. Başta Șadru'ş-şerīa'nın et-Ta’vḍiḥ’i olmak üzere hicrî sekizinci asır eserlerinde "dört delil”" (el-edilletu'l-erba‘a) şeklinde yeni bir ıstılâhî kullanımın ortaya çıtığı görülmektedir. Dört temel şer'î delil tertibinin sünni fikhında ittifak edilen dört delil anlamına geldiği aşikârdır. Bununla beraber dört mezhep arasında ittifakın yanı sıra bu dört

75 Ebū'l-Kāasim İbn Cuzey Kelbī, Takrību'l-vușūl ilā 'ilmi'l-ușūl, thk. Muhammed Hasan (Beyrut: Daru'lkutubi'l-'ilmiyye, 2003), 143.

76 İbn Cuzey Kelbī, Takrïbu'l-vuṣūl ilā 'ilmi'l-uṣūl, 176.

77 İbrāhīm b. Musā b. Muhammed el-Lahmīi Şātịī, el-Muvāfakāt, thk. Ebū ‘Ubeyde Meşhūr b. Ḥasan Alu Selmān (Huber: Dāru İbni ‘Affān, 1997), 3/165. 
delilin şer'î deliller arasındaki tertipte önem sırası da ifade ettiği, başka bir anlatımla fikhî bilgi ve hüküm üretiminde müçtehidin bu dört delilden bigâne kalamayacağı anlamı da bu tertibin manasında mündemiçtir.

\section{Kaynakça}

Āmidī, Ebû'l-Hasen Seyfuddīn ‘Alīb. Muḥammed b. Sālim es-Sa'lebī. el-İhkām fi uṣūli'l-ahkām. thk. 'Abdurrezzāk Afîfí. Beyrut: el-Mektebu'l-İslāmī, n.d.

Bāḳllānī, Ebū Bekr Muḥammed b. Ṭayyib b. Muhammed. et-Taḳib ve'lirşsād (es-șagìr). thk. 'Abdulhamīd b. 'Alī Ebū Zuneyd. b.y.: Mu'essesetu'r-risāle, 1998.

Başoğlu, Tuncay. Fikıh Usulünde Fahreddin er-Razi Mektebi. İstanbul: İSAM Yayınları, 2014.

Beyḍāvī, Nāṣiru'ddīn el-. Minhācu'l-wuṣull ilā 'ilmi'l-uṣūl. thk. Şaban Muhammed İsmail. Daru ibn Ḥazm, 2008.

Buhārī, Ebū 'Abdullah Muhạmmed b. İsmâ‘īl b. İbrāhīm. el-Cāmi'u'l-musnedu'ṣ-șahịhu'l-muhtașar min umūri Rasūlillah sallallähu 'aleyhi ve sellem ve sunenihi ve eyyāmihi. thk. Muhammed Zuheyr b. Nāṣır. b.y.: Dāru tavk en-necāt, n.d.

Cāhiz, Ebū Oșmān ‘Amr b. Bahr. Resāilu'l-Cāhiziz. Kahire: Mektebetu'l-hanc1, 1991.

Cāḥiz, Ebū Oșmān ‘Amr b. Baḥr. Kitābu'l-hayevān. Kahire: Mektebetu ve Matbaatu Mustafa el-BabielHalebī ve Evlādihi, 1965.

Ceșsāṣ, Ebū Bekr Aḥmed b. 'Alī er-Rāzī. el-Fuṣullfi'-uṣūl. thk. UceylCāsim en-Neşemī. Kuveyt: Vizāratu'levkāfi'l-Kuveytiyye, 1994.

Curcānī, 'Alī b. Muhammed. et-Ta'riffät. Beyrut: Dāru'l-kutubi'l-'ilmiyye, 1983.

Cuveynī, İmāmu'l-Ḥarameyn. el-Burhān fi ușüli'l-fikh. thk. Șalāh b. Muhammed b. 'Aveyde. Beyrut: Dāru'l-kutubi'l-'ilmiyye, 1997.

Debūsī, Ebū Zeyd 'Abdillah b. Muhammed b. 'Ömer b. İsā. Takvīmu'l-edille. thk. Hلalīl Muhyiddin elMeys. b.y.: Dâru'l-kutubi'l-'ilmiyye, 2001

Doğruyol, Feyza - Akkuş, Süleyman. “Bir İbâzî Âlim Ebû Ya'kûb el-Vercelânî’nin ed-Delîl ve'l-Burhân'1 Bağlamında İbâziyye'nin Temel Görüşleri." Sakarya Üniversitesi Illahiyat Fakültesi Dergisi (SAUIFD) 21/39 (2019),117-147. https://doi.org/10.17335/sakaifd.503092.

Ebū Ya'lā el-Ferrā', Muhammed b. Ḥuseyn b. Muhammed b. Hualef. el-'Udde fï uṣūli'l-fiḳh. thk. Aḥmed b. 'Alī el-Mubārekī. b.y.: yy., 1990.

Ebū'l-Ḥuseyn el-Bașrī, Muhammed b. 'Alīb. Tayyib. el-Mu'temed fi uṣūli'l-fiḳ. thk. Halīl Muhyiddin elMeys. Beyrut: Dāru'l-kutubi'l-'ilmiyye, 1983.

Fahreddīn er-Rāzī, Ebū 'Abdillāh Muhammed b. 'Ömer b. Ḥuseyn. el-Mahsūl. thk. Tāhā Cābir Feyyāż el-'Alvānī. Riyad: Mu'essesetu'r-risāle, 1997.

Ġazāīī, Ḥuccetu'l-îslām Ebū Ḥāmid Muhammed b. Muhammed. el-ịktișād fi'l-i'tikāad. thk. 'Abdullah Halīili. Beyrut: Dār al-kutub al- 'ilmiyyah, 2004.

Gazzālī, Ḥuccetu'l-İslām Ebū Ḥāmid Muḥammed b. Muḥammed . el-Mustașfā fì 'ilmi'l-uṣūl. thk. Muḥammed 'Abdusselām 'Abduş̧̧âfī. Beyrut: Dāru'l-kutubi'l-'ilmiyye, 1993.

Ḥāris el-Muhāsibī, Ebū 'Abdillah el-Ḥāris b. Esed. Māhiyetu'l-'akl. thk. Hüseyin El-Kuvvetli. Beyrut: Dāru'l-fikr, 1398.

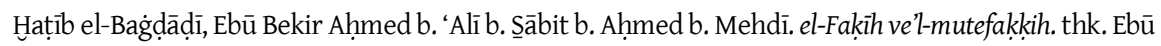
'Abdurrahıman Ādil b. Yūsuf El-Ġarrāzī. Suudi Arabistan: Dāru İbnu'l-cevzī, 2000.

İbn Bereke, 'Abdullah b. Muhammed. Kitābu'l-cāmi . Umman: Vizāretu't-Turās ve'ś-S̄ekāfe, 2007.

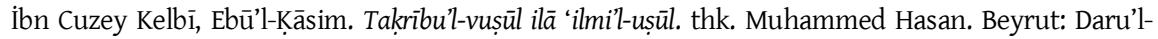
kutubi'l-‘'lmiyye, 2003.

İbn Fūrek, Ebū Bekir Muhammed. el-Hudūd fìl-uṣūl. thk. Muhammed Süleymani. Beyrut: Dāru'lgarbi'l-ìslāmī, 1999.

İbn Ḥabīb el-Ḥalebī, Ṭāhir b. el-Ḥasan. Muhtașaru'l-menār. İstanbul: Süleymaniye Kütüphanesi, 
Kadızade Mehmed, 550.

İbn Ḳudāme, Ebū Muhammed Muvaffaḳuddīn 'Abdullah b. Ahmed b. Muhammed. Ravdatu’n-nāzır ve cunnetu'l-munāẓır fì ușūli'l-fiḳh 'alā mežhebil'-Imām Aḥmed b. Hanbel. thk. 'Abdulkerìm b. 'Alī b. Muhammed En-Nemle. Riyad: Mu'essesetu'r-reyyān, 2002.

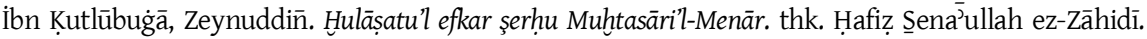
b.y.: Daru ibn Ḥazm, 2003.

İbn Manẓūr, Ebū'l-Faḍl Cemālüddīn Muhammed b. Mukerrem. Lisānu'l-'Arab. Beyrut: Daru Sâdr, 1414. İbn Muflīḥ, Ebū 'Abdillah Şemsuddīn Muḥammed. Ușūlu'l-fiḳ. thk. Fehd b. Muḥammed es-Sedhān. b.y.: Mektebetu 'Abyikān, n.d.

İbn ‘Ābidīn, Muhammed Emīn. Nesemātu'l-eshār. Karaçi: İdaretu'l-Kur'ān ve'l-Ulumi'l-İslāmiyye, 1997. İbn 'Akịil, Ebū'l-Vefā 'Alī b. 'Akịl b. Muhammed. el-Vādih fị ușūli'l-fiḳh. thk. 'Abdullâh b. 'Abdulmuḥsin et-Turkî. Beyrut: Mu'essesetu'r-risâle, 1999.

İbnu'ș-Ṣalāh, Ebū Amr Takiiyyuddīn. Edebu'l-muftī ve'l-musteftī. thk. Muvaffak Abdulkadir. Medine: Mektebetu'l-'Ulūm ve'l-Hikem, 2002.

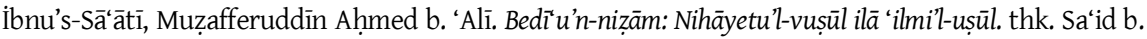
Garîr b. Mehdî es-sulemî. Mekke: y.y., n.d.

İșfahānī, Maḥmūd b. 'Abdurraḥmān el-. Beyānu'l-muhtașar. thk. Mahmud Muzhir Beka. y.y.: Dāru'lMedenī el-Muessesetu's-Su'ūdiyye bi-Mișra, 1986.

Ḳāḍī Nu'mān, Ebū Ḥanīfe. İhtilafu ușūli'l-mezzāhib. Beyrut: Dāru'l-Endelus, 1983.

Kāaī 'Abdulcabbar, Ebū'l-Ḥasen b. Ahmed. Şerḥu uṣulli'l-hamse. thk. 'Abdulkerim Oșmān. Kahire: Mektebetu Vehbe, 1996.

Karāfī, Ebū 'Abbās Şehābeddīn Aḥmed b. İdrīs. el-Furūḳ envārul-burūḳ fì envāil-furūk. thk. 'ālem'ul Kutub.b.y.: y.y., n.d.

Kasapoğlu, Saliha. "Şer’̂̂ Delillerde Öncelik Meselesinin Mezhep-Delil Perspektifinden Tahlili Ve Anlama Yöntemine Etkileri.” Hitit Üniversitesi İlahiyat Fakültesi Dergisi 17/34 (2018),763-776. https://doi.org/10.14395/hititilahiyat.464842.

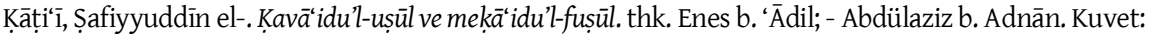
Dāru'r-rekāiz, 2018.

Mahațverī, Murtaḍā b. Zeyd. ez-Zeydiyye. thk. Yahyya el-Ceyūrī. San'a: Mektebetu Bedr, 2014.

Melek, İbn. Şerḥu menāri'l-envār. Beyrut: Daru'l-Kutubi'l-'İlmiyye, 1308.

Nesefī, Ebu'l-Berekāt Ḥāfıẓuddīn ‘Abdullah b. Aḥmed b. Maḥmūd. Şerḥu'l-muntehab. thk. Salim Öğüt. İstanbul: y.y., 2003.

Rāzī - Ebū 'Abdullāh Muhammed b. 'Omer b. el-Ḥasan b. el-Ḥuseyn et-Teymī er-Rāzī. Mefâtīhu’l-g̣ayb et-tefsìru'l-kebīr. Beyrut: Dāru İhya' et-Turās el-'Arabī , 1420.

Șadru'ş-şerīa, 'Ubeydullah b. Mes'ûd el-Mahbûbî. et-Tavḍih fi halli ġavāmiḍit-tenkịh (Telvīh içinde). y.y: Mektebetu Sabīh bi-Mișr, n.d.

Şāfiīi, Muḥammed b. İdrīs. er-Risāle. n.d.

Şāțibī, İbrāhīm b. Musā b. Muhammed el-Lahmī. el-Muvāfakāt. thk. Ebū ‘Ubeyde Meşhūr b. Ḥasan Alu Selmān. Huber: Dāru İbni 'Affān, 1997.

Semerḳandī, Alāu'd-dīn Ebū Bekir Muhammed b. Aḥmed. Mĩzānul'-uṣūl fi netā'ici'l-ukūul. thk. Muhammed Zekî 'Abdilberr. Katar: Mațâbi'u'd-Dûha'l-hadîse, 1984.

Sem‘ānī, Ebū'l-Muẓaffer Manșūr b. Muhammed es-. Kavāțti u'l-edille fi'l-uṣūl. thk. Muhammed Ḥasan Muhammed Ḥasan İsmāâil. Beyrut: Dāru'l-kutubi'l-'ilmiyye, 1999.

Serahsīi, Muhammed b. Aḥmed b. Ebī Sehl Şemsu'-eimme. Ușūlu's-Serahsīi. thk. Ebû'l-Vefā el-Efgānī. Beyrut: Dāru'l-ma'rife, 1973.

Şemsu'd-dīn, Mușțafā Muhammed Cebrī. Tertïbu'l-edilleti'ş-şeriyye el-muttafak 'aley hā 'inde'l-cumhūr ve tenziluhu min hilāli kaḍāyā't-ta'ārudi ve't-tercịh. Malezya: Uluslararası İslam Üniversitesi, Yüksek Lisans Tezi, 2005.

Şeybani, Ebu Abdullah Muhammed b. Hasan b. Ferkad el-Hanefi. el-Hücce alâ ehli'l-Medine. thk. Mehdi 
Ḥasen el-KeylânîEl-Kââîîi. Beyrut: 'Alemü'l-kütüb, 1982.

Şeyh et-Tūsī, Ebū Ca'fer. el-'Udde fi uṣūli'l-fiḳh. thk. Muhammed Mehdi Necej. Muessesetu Āli Beyt, n.d. Seyyid el-Murtad̄ā. ez-Zerīa $a$. thk. Ebū'l-Kāsim el-Kercī. Tahran: Danişgah, 1927.

Şīāzī, Cemāluddīn İbrāhim b. 'Alī b. Yūsuf Ebū İshāạ. el-Luma' fi ușūli'l-fiḳh. b.y.: Dāru'l-kutubi'l‘ilmiyye, 2003.

Temel, Ahmet. "Ușūl al-sunna: The Tenets of Islamic Orthodoxy and Orthopraxy According to the Traditionalists (Ahl al-hadīth)." In The Sunna and its Status in Islamic Law. thk. Adis Duderija. 3957. New York: Palgrave Macmillan, 2015. https://doi.org/10.1057/9781137369925_3.

Temel, Ahmet. "Was There a Zaydī Ușūl al-fiqh? Searching for the Essence of Zaydī Legal Theory in the First Complete Ușūl Work of Zaydīs: al-Nātiq bi-l-haqq’s (340-424/951-1033) 'al-Mujzī fī ușūl al-fiqh."' Insan \& Toplum Dergisi (The Journal of Human \& Society) 6/1 (June 3, 2016),71-83. https://doi.org/10.12658/human.society.6.11.m0142.

Usmendī, Alāeddīn. Bežlu'n-nazar. thk. Muhammed Zeki Abdülberr. Kahire: Mektebetu't-turās, 1992.

Vercelānī, Ebū Ya'ḳūb el-. ed-Delil ve'l-burhān. thk. Sālim el-Hāarisīi. Umman: Vizāretu't-Turās ve'śŚekāfe, 2006.

Vercelānī, Ebū Ya'kūūb.el-'Adl ve'l-inșāf. Umman: Vizāretu't-Turās̄ ve's-s-Sekāâfe, 1983.

'Abdul'azīz el-Buhārī, 'Alāuddīn 'Abdulazīz b. Ahmed. Keş̧fu'l-esrār Şerhu Ușūli'l-Pezdevī. b.y.: Dāru'lkitābi'l-islāmiyye, n.d.

'Askerī, Ebū Hilāl. el-Evā'il. Ṭanța: Dāru'l-beşīr, 1408.

‘Askerī, Ebū Hilāl. el-Furūku'l-lugaviiyye. thk. Muhammed İbrahim Selim. Kahire: Dāru'l-'ilm ve’śekāfe, n.d.

'İzzeddīn b. 'Abdusselām, Ebū Muḥammed. Kavātidu'l-aḥkām fì meșālihị'l-enām. thk. Ṭāha Abdurraūf Sa'id. Kahire: Mektebetu el-kulliyāti'l-ezheriyye, n.d.

'Ubeydi'l-Cubeyrī, Kāsım b. Hualef Ebū. et-Tevassuṭ beyne Mālik ve İbni'l-Kāsım fi'l-mesāili'l-letīi ihtelefā fihā min mesāili'l-Mudevvene. thk. Baḥu Mușțafa. Mıșır: Dāru'z-ẓıā, 2005.

'Ukberi, İbn Şihāāb. Risāle fi uṣūli'l-fiḳh. thk. Muvaffaḳb. 'Abdillāh b. 'Abdilkādir. Mekke: el-Mektebetu'lMekkiyye, 1992. 